\title{
Carbon and nitrogen cycling on intertidal mudflats of a temperate Australian estuary. III. Sources of organic matter
}

\author{
Perran L. M. Cook ${ }^{1,2,3,5, *}$, Andrew T. Revill ${ }^{2,3,4}$, Lesley A. Clementson ${ }^{2}$, John K. Volkman ${ }^{2,4}$ \\ ${ }^{1}$ University of Tasmania, GPO Box 252-75, Hobart, Tasmania 7001, Australia \\ ${ }^{2}$ CSIRO Marine Research, GPO Box 1538, Hobart, Tasmania 7001, Australia \\ ${ }^{3} \mathrm{CRC}$ for Coastal Zone, Estuary and Waterway Management, Indooroopilly Sciences Centre, \\ 80 Meiers Road, Indooroopilly, Queensland 4068, Australia \\ ${ }^{4}$ Aquafin CRC, PO Box 120, Henley Beach, South Australia 5022, Australia \\ ${ }^{5}$ Present address: Max Planck Institute for Marine Microbiology, Celsiusstrasse 1, 28359 Bremen, Germany
}

\begin{abstract}
The sources and cycling of organic matter on 2 mudflats in the Huon Estuary, SE Tasmania, were investigated over 4 seasons using pigment and lipid biomarkers as well as stable isotopes of carbon and nitrogen; 1 site was in the upper estuary, 1 site was in a marine side-arm. The organic matter within the sediments at both sites was dominated by terrestrial sources, but most of this was refractory and only slowly remineralised. Significant, but seasonally variable, amounts of organic matter were derived from microphytobenthos (MPB), but this was rapidly remineralised and comprised only a minor fraction of the preserved sediment organic matter pool. Compound specific stable-isotope analysis of bacterial biomarkers suggested that the bacteria within the sediment were consuming microalgae-derived material. Separation of MPB from the sediment at the site in the upper estuary using the lens-tissue technique was found to significantly fractionate the algae community with cyanobacteria being enriched in the separated fraction. Nitrogen fixation probably contributed significantly to the growth requirements of cyanobacteria at the site in the upper estuary, as indicated by the low $\delta^{15} \mathrm{~N}$ value of the cyanobacteria separated from the sediment.
\end{abstract}

KEY WORDS: Microphytobenthos - Stable isotope $\cdot$ Compound-specific isotope-ratio mass spectrometry · Fatty acids - Sterols · Accessory pigment · Mudflat

Resale or republication not permitted without written consent of the publisher

\section{INTRODUCTION}

The unique position of mudflats at the interface between the land and sea means that organic matter originating from a wide range of terrestrial and marine sources may be deposited within these environments. This may include organic matter exported from adjacent communities, including mangroves and saltmarshes (Meziane et al. 1997, Meziane \& Tsuchiya 2000), terrestrially eroded material such as peats (Volkman et al. 2000), as well as the discharge of organic matter from anthropogenic sources (Meziane \& Tsuchiya 2002). Autochthonous production of organic matter by microphytobenthos (MPB), macroalgae and bacteria may contribute significantly to the organic matter pool within mudflat sediments (Volkman et al. 1980, Meziane et al. 1997, Meziane \& Tsuchiya 2000, 2002). Detritus from marine sources, such as seagrasses, as well as phytodetritus from pelagic algae blooms have also been identified as contributing to organic matter on mudflats (Volkman et al. 1980, Rohjans et al. 1998).

The classes of algae present on the mudflat may also have significant implications for the ecological functioning of the system. Most studies to date have shown that the MPB on mudflats is dominated by diatoms (Cariou-Le Gall \& Blanchard 1995, Barranguet et al. 1997, Brotas \& Plante-Cuny 1998, Lucas \& Holligan 
1999, Cahoon \& Safi 2002), but this may shift seasonally to chlorophytes and cyanobacteria (Barranguet et al. 1997). In some areas, intertidal sediments may be dominated by cyanobacteria where high rates of nitrogen fixation may supply a significant amount of nitrogen to the benthic community (Stal et al. 1984, Bautista \& Paerl 1985, Stal 1995).

A number of approaches have been used to estimate the contributions of organic matter from various sources to sediments. Isotope ratios of ${ }^{13} \mathrm{C} /{ }^{12} \mathrm{C}$ have been used to estimate the relative contribution of terrestrial and marine sources to sedimentary organic matter (Fry \& Sherr 1984). While this approach is relatively simple and gives an integrated estimate of sources for the total carbon in the sample, it will only provide useful information when there are 2 welldefined end-members. Furthermore, this technique gives little information about the type of marine or terrestrial organic matter in question.

The use of lipid and pigment biomarkers such as fatty acids and sterols can allow the sources of various subfractions of organic matter to be identified much more specifically than any of the above approaches. However, unambiguously assigning sources to biomarkers is difficult, as they are rarely produced by a single class of organism. The advent of compound-specific stableisotope analysis has provided a powerful new tool for the differentiation between 2 sources of the same biomarker, provided the isotopic signatures of the 2 sources are different. The use of compound-specific stable-isotope analysis also allows a greater understanding of the flows of carbon through the microbial food web because, in general, the isotopic signature of heterotrophic organisms will be similar to that of their food source (Boschker \& Middelburg 2002).

A number of approaches exist to identify the presence of microalgal classes and estimate their relative abundance. Simple visual methods have commonly been used, but they are laborious, and microscopic cells are difficult to identify and count on a large scale (Brotas \& Plante-Cuny 1998, Cabrita \& Brotas 2000). The presence of sediment often interferes with a range of measurements including cell-counting, algal $\mathrm{C}: \mathrm{N}$ ratios and stable-isotope measurements, so it can be advantageous to separate the MPB from the sediment for these measurements (Couch 1989, Cabrita \& Brotas 2000). MPB can be separated from intertidal sediments by covering them with a lens-tissue (Eaton \& Moss 1966), although differences in the mobility of algae within the MPB may lead to a bias against less mobile taxa. We are not aware of any studies which have investigated this possibility.

Another means of distinguishing algal classes is through the use of carotenoid accessory pigments (Jeffrey \& Vesk 1997). Fatty acids also offer the poten- tial to distinguish various algal classes (Volkman et al. 1989, 1998), although these may be less specific than pigments. Using these methods to estimate the relative importance of algal classes requires an estimate to be made of the ratios of pigments and fatty acids to a measure of biomass such as chlorophyll $a$ (chl a). These may not necessarily be accurate, as the ratios of pigments and fatty acids can change, depending upon environmental conditions (Thompson et al. 1990, Porra et al. 1997).

To date, most studies of mudflats have generally only used 1 or 2 of the above-mentioned techniques to study the ecological processes occurring in these systems. In this study we have combined a range of modern methods to gain a detailed understanding of the sources and cycling of organic matter on 2 mudflats in a temperate Australian estuary. The specific aims of this study were to (1) identify the sources of organic matter to the sediments, using lipid biomarkers; (2) identify the classes of algae present on the mudflat using pigment and lipid biomarkers; (3) obtain an estimate of the relative importance of these sources both in terms of the preserved organic matter pool and as substrates for sediment respiration, using stable-isotope analysis of both bulk and lipid fractions of organic matter.

\section{MATERIALS AND METHODS}

Sampling. Sediments: Samples were collected from the upper and lower mudflats at 2 sites, Castle Forbes Bay (Site CF) and Port Cygnet (Site PC) in the Huon Estuary, in SE Tasmania, Australia. The sample sites on the upper and lower mudflat were $\sim 50 \mathrm{~m}$ apart and had an elevation difference of $\sim 0.5 \mathrm{~m}$ at both sites, the tidal range within the estuary was $\sim 1 \mathrm{~m}$. Site CF is located in the upper estuary and is euryhaline, while Site PC is more saline and is located in a marine-dominated side-arm of the estuary. In spring and summer, Site PC had an approximately $50 \%$ cover of the macroalgae Gracillaria sp. During autumn and winter this was greatly reduced to $\sim 10 \%$. For a more detailed description of the study sites and the estuary see Cook et al. (2004a, this volume). Samples were collected from Site CF in March, June, September and December 2001. At Site PC samples were collected during April, June, September and December 2001. To facilitate comparison with other measurements, March and April are referred to as autumn; June, September and December are referred to as winter, spring, and summer, respectively. The samples for biomarker, $\% \mathrm{C}, \% \mathrm{~N}$ and stable-isotope analysis were sub-sampled from cores which had previously been sampled and incubated for process measurements as described in Cook et al. (2004a) and Cook et al. (2004b, this volume). 
Briefly, 4 intact sediment cores $(25 \times 14.5 \mathrm{~cm}$ inner diameter [i.d.]) were taken from the upper and lower mudflats at each site by wading out onto the mudflat. Samples on the upper and lower mudflats were taken by hand within several metres of each other, avoiding any visible vegetation. Samples at each site were collected at low tide, when the water on the lower mudflat was $<0.5 \mathrm{~m}$ deep. Immediately after sediment incubations had been performed, the top $0.5 \mathrm{~cm}$ of sediment was collected with a spatula from half of each core and a $4 \mathrm{ml}$ sub-sample was placed in cryovials and frozen in liquid nitrogen $\left(-176^{\circ} \mathrm{C}\right)$ for later pigment analysis. For the fatty acid, sterol, stable isotope, \%C and $\% \mathrm{~N}$ analysis, a second $10 \mathrm{ml}$ subsample was frozen at $-20^{\circ} \mathrm{C}$. Because fatty acid analysis requires more biomass, 4 replicate samples from each site were pooled in equal proportions prior to extraction and analysis.

Separation of microphytobenthos: MPB were separated from the sediment using the lens-tissue method described by Eaton \& Moss (1966). Briefly, 4 cores of sediment (i.d. $=6.5 \mathrm{~cm}$ ) were taken from the 2 study sites and returned to the laboratory. We then placed 2 layers of lens-tissue (Kimwipes ${ }^{\circledR}$, Kimberly Clark) on the sediment surface. The cores were then left in the dark at ambient laboratory temperature $\left(20^{\circ} \mathrm{C}\right)$ overnight and the top layer of lens-tissue was removed the following day. Prior to the analysis of pigments, the lens-tissue was frozen under liquid nitrogen. Samples of lens-tissue for analysis of stable isotopes, sterols and fatty acids were placed in a vial of $\mathrm{NaCl}$ solution (15 $\mathrm{g} \mathrm{l}^{-1}$ ) and agitated to resuspend the microalgae back into solution. The algal suspension was taken up in a syringe and filtered through a pre-combusted $25 \mathrm{~mm}$ Whatman GF/F glass-fibre filter. The filter containing the microalgae was frozen at $-20^{\circ} \mathrm{C}$ until analysed. Lens-tissue samples with no algae present (blanks) were treated in an identical fashion to ensure that carbon derived from the lens-tissue did not interfere with the analysis of the separated MPB.

To investigate the sampling bias of the MPB community caused by the lens-tissue method, an experiment was undertaken using pigment biomarkers. We collected 6 sediment cores from the upper mudflat at Site CF. The surface sediment of 3 cores was sampled immediately by extruding the cores and slicing off the top $0.5 \mathrm{~cm}$ with a spatula; these samples were frozen under liquid nitrogen for later pigment analysis. The MPB in the remaining 3 cores were separated from the sediment using the lens-tissue method as described above. MPB separated in this manner was subsequently frozen for pigment analysis. After the separation of MPB from the sediment, the top $0.5 \mathrm{~cm}$ of sediment was taken from these cores also. The lens-tissue and sediment samples were then stored under liquid nitrogen until used for pigment analysis.
Analytical methods. Microscopy: Visual observations of algae separated from the sediments were made using a Zeiss Axioplan compound microscope. Selected samples were photographed using a Zeiss Axiocam mounted on a Leica DMIRB inverted microscope. Images were captured using Axiovision software.

Lipid biomarkers: Sediment samples were extracted 3 times by a 1-phase chloroform-methanol-water mixture (1:2:0.8 v/v/v) according to a modified version of the Bligh \& Dyer method (Bligh \& Dyer 1959). An aliquot of the total extract was taken for alkaline saponification with $3 \mathrm{ml}$ of $5 \% \mathrm{KOH}$ in methanol:water (80:20) and heated at $80^{\circ} \mathrm{C}$ for $2 \mathrm{~h}$. The neutral and fatty acid fractions were subsequently extracted before and after acidification, respectively. Fatty acid methyl esters (FAMEs) were formed by treating the fatty acid fraction with $\mathrm{MeOH}: \mathrm{HCl}$ at $80^{\circ} \mathrm{C}$ for $2 \mathrm{~h}$ and extracting into hexane:chloroform (4:1). The neutral fractions were treated with bis(trimethylsilyl) trifluoroacetamide (BSTFA, $100 \mu \mathrm{l}, 60^{\circ} \mathrm{C}, 60 \mathrm{~min}$ ) to convert hydroxylated compounds such as sterols and alcohols to their trimethylsilyl (TMSi) ethers.

Gas chromatography (GC) was initially performed using a Varian CP 3800. For the analysis of the neutral fraction, the gas chromatograph was equipped with a $50 \mathrm{~m} \times 0.32 \mathrm{~mm}$ i.d. cross-linked $5 \%$ phenyl-methyl silicone (HP5, Hewlett Packard), fused-silica capillary column. The total fatty acid fraction (as methyl esters) was analysed on the same instrument, except that the samples were injected through an SPI (septum programmable injector) injector onto a $50 \mathrm{~m} \times 0.32 \mathrm{~mm}$ i.d. cross-linked $1 \%$ phenyl-methyl silicone (HP1, Hewlett Packard), fused-silica capillary column. Sterol and fatty acid fractions were analysed using a flame ionisation detector (FID), with 5 $3(\mathrm{H})$-cholestan-24-ol as the internal standard for sterols and the methyl ester of tricosanoic acid as the internal standard for fatty acids. Peak identifications were based on retention times relative to authentic and laboratory standards and subsequent GC-MS analysis. The detection limit for individual sterols and fatty acids was approximately $0.2 \mathrm{mg} \mathrm{m}^{-2}$ of $0.5 \mathrm{~cm}$ deep sediment.

Verification of the identity of individual sterols and fatty acids by GC-MS analyses was performed on a Thermoquest/Finnigan GCQ-Plus bench-top mass spectrometer fitted with a direct capillary inlet and an automated on-column injector. Data were acquired in scan acquisition or selective ion monitoring. The nonpolar column (HP5) and operating conditions were the same as that described above for the GC-FID analyses, except that helium was used as the carrier gas.

Pigment biomarkers: Sediments were extracted twice in $100 \%$ acetone over $24 \mathrm{~h}$ at $4^{\circ} \mathrm{C}$ (after extraction water had been added to achieve a final mixture of 90:10 acetone:water by volume), and filtered (0.2 $\mu \mathrm{m}$ mem- 
brane filter, Whatman, Anatope) for immediate analysis by HPLC. Pigment analysis used a Waters highperformance liquid chromatograph, comprising a 600 controller, 717 plus refrigerated autosampler, and a 996 photodiode array detector. Pigments were separated as described by Wright et al. (1991), detected at $436 \mathrm{~nm}$, and identified against standard spectra. Concentrations of chl $a$, chlorophyll $b(\mathrm{chl} b), \beta$, $\beta$-carotene, and $\beta, \varepsilon$-carotene in sample chromatograms were determined from standards, and all other pigment concentrations were determined from standards of purified pigments isolated from algal cultures.

Stable isotopes and \% organic carbon and nitrogen: Algal samples on glass-fibre filters were fumed over $\mathrm{HCl}$ to remove any carbonates present, and dried at $60^{\circ} \mathrm{C}$ for several hours before being divided and placed into tin cups (Elemental Microanalysis) for analysis. Sediment samples for stable-isotope analysis were dried in an oven overnight at $60^{\circ} \mathrm{C}$ before being ground with a mortar and pestle. Sediment samples were weighed into tin cups for nitrogen analysis. For the analysis of carbon, samples were weighed into aluminium cups and were subsequently sequentially acidified using sulphurous acid to remove any mineral carbonates (Verardo et al. 1990). Samples were analysed for nitrogen and carbon contents, $\delta^{15} \mathrm{~N}$ and $\delta^{13} \mathrm{C}$, using a Carlo Erba NA1500 CNS analyser interfaced via a Conflo II to a Finnigan Mat Delta S isotope-ratio mass spectrometer operating in the continuous-flow mode. Combustion and oxidation were achieved at $1090^{\circ} \mathrm{C}$ and reduction at $650^{\circ} \mathrm{C}$. Where necessary (because of high carbon contents) the carbon signal was quantitatively diluted with helium. Samples were analysed at least in duplicate. Results are presented in standard $\delta$ notation:

$$
\delta^{15} \mathrm{~N} \text { or } \delta^{13} \mathrm{C}(\%)=\left[\frac{R_{\text {sample }}}{R_{\text {standard }}}-1\right] \times 1000 \%
$$

where $\mathrm{R}={ }^{13} \mathrm{C} /{ }^{12} \mathrm{C}$ or ${ }^{15} \mathrm{~N} /{ }^{14} \mathrm{~N}$. The standard for carbon is Vienna PeeDee Belemnite (VPDB) and the standard for nitrogen is atmospheric $\mathrm{N}_{2}$. The reproducibility of the stable-isotope measurements was $\pm 0.2 \%$ for $\mathrm{C}$ and $0.5 \%$ for $\mathrm{N}$.

Compound-specific stable-isotope-ratio analysis: Compound-specific isotope-ratio mass spectrometry was performed on selected sediment extracts using a Hewlett Packard 5890 Series II gas chromatograph, which was coupled via a Finnigan MAT GC combustion interface to the isotope-ratio mass spectrometer described above. The gas chromatograph was equipped with a $60 \mathrm{~m} \mathrm{J \& W} \mathrm{DB-1,} 0.32 \mathrm{~mm}$ i.d. column, with He as the carrier gas. Samples were injected on-column via a cold on-column injector ('Duck Bill', Hewlett Packard). The initial oven temperature of $40^{\circ} \mathrm{C}$ was maintained for $1 \mathrm{~min}$ followed by a $30^{\circ} \mathrm{C} \mathrm{min}^{-1} \mathrm{ramp}$ rate up to $120^{\circ} \mathrm{C}$ followed by a $4^{\circ} \mathrm{C} \mathrm{min}^{-1}$ ramp rate up $315^{\circ} \mathrm{C}$, which was held for $15 \mathrm{~min}$. Samples were coinjected twice with $\mathrm{C}_{16}$ and $\mathrm{C}_{24}$ deuterated $n$-alkanes of known isotopic composition; the average of the 2 injections is reported here. To obtain the ratio of the biomarker compounds, the carbon isotope ratio of the derivatised samples were corrected for the number of carbon atoms that had been added during derivatisation (3 for TMSi ethers and 1 for FAMEs) as described by Boschker et al. (1999). Results are presented in standard $\delta$ notation as described above.

\section{RESULTS}

\section{Stable isotopes, organic matter content and $\mathrm{C}: \mathrm{N}$ ratio}

At Site $\mathrm{CF}$, the organic carbon content per dry weight of sediment was always greater $(5 \%)$ than at Site PC (3\%) (Fig. 1c), where the sediment was finest and coarsest, respectively (Cook et al. 2004a). At Site $\mathrm{CF}$, the organic carbon content was not significantly different between the upper and lower mudflats (1-way ANOVA), while the organic carbon content was significantly higher on the lower mudflat at Site PC ( $p<0.01)$. The bulk C:N ratio of the organic matter tended to be higher at Site CF than at Site PC.

The $\delta^{13} \mathrm{C}$ values at all sites were between -26 and $-23 \%$ over the course of the year. At Site CF, the most enriched $\delta^{13} \mathrm{C}$ values were observed during spring, coinciding with the highest chl $a$ values and greatest productivity on the upper mudflat (Cook et al. 2004a). At Site PC upper, the carbon isotope signature of the mudflat remained relatively constant throughout the year, whereas on the lower mudflat it became more depleted between January and December. The $\delta^{15} \mathrm{~N}$ at Site CF ranged between 1 and $3 \%$ on the upper mudflat and between 0 and $2 \%$ on the lower mudflat. At Site PC, $\delta^{15} \mathrm{~N}$ ranged from 2.5 to $5 \%$ and was generally greater than at Site CF.

At Site $\mathrm{CF}$, the isotopic signature of MPB was consistently in the range of -14 to $-17 \%$ for $\delta^{13} \mathrm{C}$ and 1.5 to $2.8 \%$ for $\delta^{15}$ N. Snails Salinator solida taken from the mudflat at Site CF had a $\delta^{13} \mathrm{C}$ of $-14.5 \%$ and a $\delta^{15} \mathrm{~N}$ of $\sim 3 \%$, similar to that of the local MPB (Table 1). At Site $\mathrm{PC}$, the MPB was isotopically more depleted for carbon $\left(\delta^{13} \mathrm{C}\right.$ of $-20.5 \%$ o) and isotopically enriched for nitrogen $\left(\delta^{15} \mathrm{~N}\right.$ of $7.1 \%$ ). Macroalgae Gracilaria sp. collected from Site PC had a $\delta^{13} \mathrm{C}$ of $-19 \%$ and a $\delta^{15} \mathrm{~N}$ of $8.4 \%$. Terrestrial sources of organic matter including that from creek sediments and plant detritus consistently had a $\delta^{13} \mathrm{C}$ more depleted than $-27.5 \%$ and a $\delta^{15} \mathrm{~N}$ more depleted than $2 \%$. The marsh reed Juncus kraussi had an intermediate signature of $-26 \%$ for $\delta^{13} \mathrm{C}$ and $3.5 \%$ for $\delta^{15} \mathrm{~N}$. 

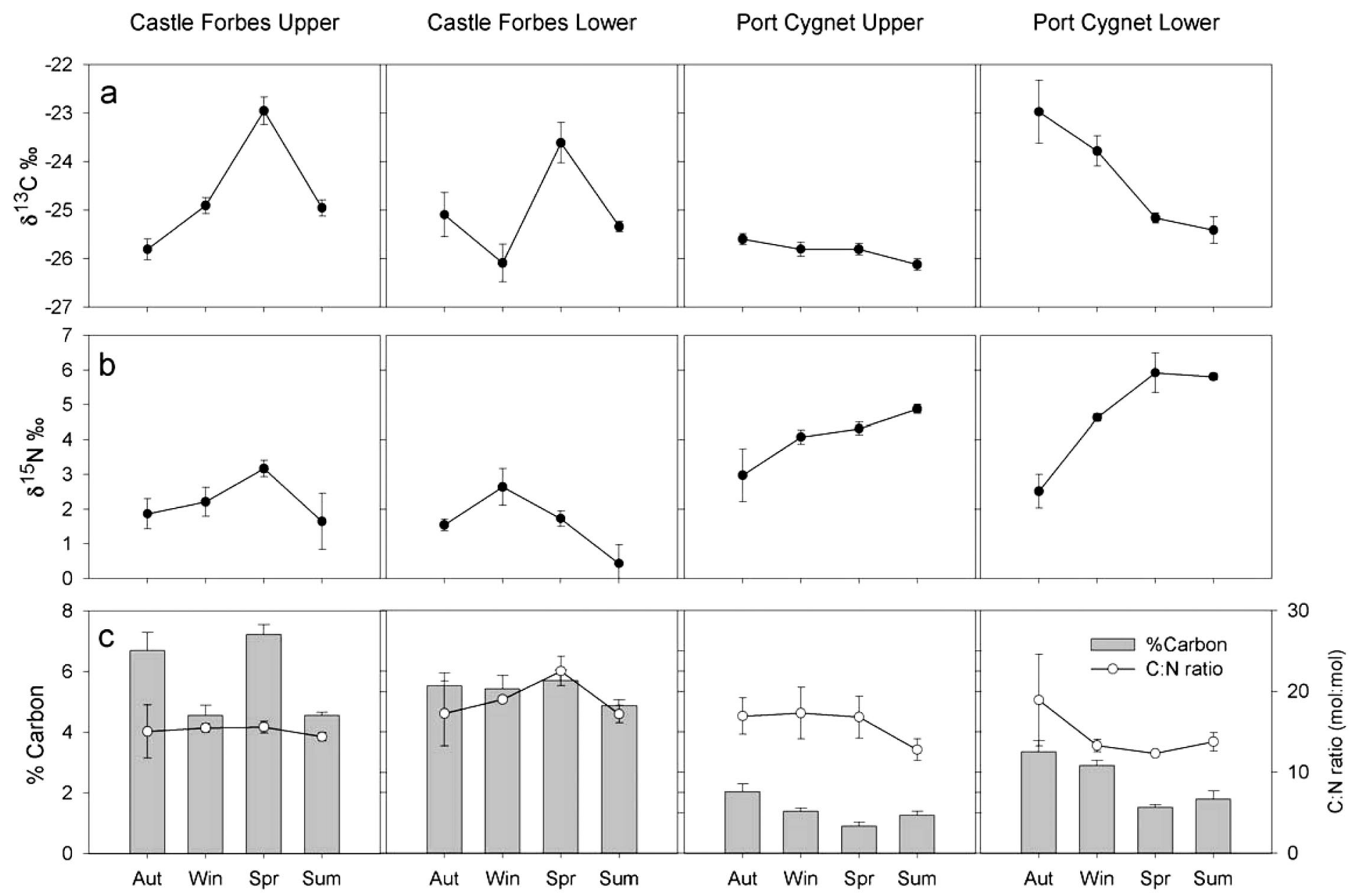

Fig. 1. (a) $\delta^{13} \mathrm{C}$, (b) $\delta^{15} \mathrm{~N}$ and (c) \% carbon and C:N ratios measured in top $0.5 \mathrm{~cm}$ of sediment in autumn (Aut), winter (Win), spring (Spr) and summer (Sum) at the 2 study sites in 2001. Error bars: SE of mean ( $\mathrm{n}=3$ to 4 , except for $\delta^{15} \mathrm{~N}$ of Port Cygnet lower during summer, where $n=1$ )

\section{Biomarkers}

Algal pigments. Carotenoids detected included lutein, zeaxanthin, fucoxanthin, diatoxanthin and diadinoxanthin. These pigments can be used as biomarkers for various algal classes. In this study, lutein was used as a marker for chlorophytes, zeaxanthin for cyanobacteria and fucoxanthin for diatoms (Jeffrey \& Vesk 1997). Chlorophyll $C(\mathrm{chl} c)$ was also present as well as small amounts of chl $b$ on occasions. Fucoxanthin (fuc) was detected at all sites throughout the year, and generally had a fuc:chl a ratio of $<0.1$ (Fig. 2). Lutein (lut) generally dominated the accessory pigments at all sites during autumn and winter, with lut:chl a ratios of up to 0.4 recorded on the upper and lower mudflats at Site PC. Zeaxanthin (zea) was detected at all times of the year

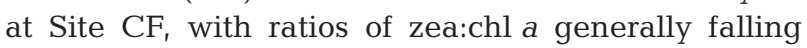
within the range of 0.01 to 0.04 . At Site PC, zeaxanthin was present in the highest proportions during spring and summer on the upper and lower mudflats with zea:chl a ratios of up to 0.3 being observed. The alga Vaucheria sp. (Xanthophyta) was observed at Site CF during spring; however, the vaucheriaxanthin ester and violaxanthin, particular to this class (Jeffrey \& Vesk 1997), were not detected.

Sterols. Total sterol concentrations varied between 77 and $550 \mathrm{mg} \mathrm{m}^{-2}$ (Fig. 3) and were highest on the upper mudflat at Site CF during spring. The relative composition of the sterol biomarkers were generally similar throughout the year (Table 2), suggesting the organic matter was derived from the same sources; but absolute amounts varied considerably. Sterol composition was consistent between the upper and lower mudflats and between the 2 sites. Total sterols were highly correlated with chl $a(\mathrm{r}=0.93, \mathrm{p}<0.01)$ and phytol $(\mathrm{r}=0.97, \mathrm{p}<$ 0.01 ). The sterol fraction was dominated by 24 -ethylcholest-5-en-3 $\beta$-ol (sitosterol and/or clionosterol) at all sites throughout the year, comprising between 17 and 
$38 \%$ of total sterols. The microalgal marker 24-methylcholesta5,22E-dien-3 $\beta$-ol (brassicasterol and/or crinosterol) comprised between 10 and $18 \%$ of total sterols at Site CF and between 6 and $14 \%$ of total sterols at Site PC. The dinoflagellate marker $4 \alpha, 23,24$ trimethyl- $5 \alpha$-cholest-22E-en-3 $\beta$-ol (dinosterol) was detected infrequently in the sediments at both sites, but followed no apparent seasonal pattern, and was generally less than $5 \%$ of total sterols.

Stanols. Stanols (i.e. sterols in which the double bond at C-5 is reduced) were present in all sediments. Most of these are derived from in situ reduction, but some faecal markers such as $5 \beta$-cholestan-3 $\beta$-ol (coprostanol) and 24ethyl-5 $\beta$-cholestan- $3 \beta$-ol were detected at Port Cygnet, with concentrations being greater on the upper mudflat than the lower mudflat throughout the year (Table 2); 24-ethyl-5 $\alpha$-cholestan$3 \beta$-ol (sitostanol) was a major component of the total sterol fraction, comprising between 3 and $9 \%$ of total sterols at $\mathrm{CF}$ and between 6 and $11 \%$ of total sterols at Site PC. The stanol:sterol (total stanols:total sterols) ratio at Site PC (0.70 to 0.85$)$ was much greater than at Site CF (0.30 to 0.57).

Phytol. Phytol concentrations varied between 17 and $642 \mathrm{mg} \mathrm{m}^{-2}$ (Fig. 3). Phytol was converted to chl a equivalents using a multiplication factor of 3 to correct for the differences in molecular mass (296 compared to 893 for chl a). After this correction chl a equivalents of phytol were always in excess of the actual chl a concentration measured by HPLC by a factor of between 2.5 and 6 , indicating that much of the phytol was no longer associated with the chlorophyll molecule.

Fatty acids. The total concentrations of fatty acids on the mudflats ranged between 57 and $822 \mathrm{mg} \mathrm{m}^{-2}$ (Fig. 3). Fatty acid concentrations were highest on the upper mudflat at Site CF (1-way ANOVA, Fisher's least-significant difference [LSD] post hoc, $\mathrm{p}<0.001$ ), where rates of primary production and MPB biomass were highest (Cook et al. 2004a). Total fatty acids were correlated with chl a $(\mathrm{r}=0.88, \mathrm{p}<0.01)$ and net primary production $(\mathrm{r}=0.58, \mathrm{p}<0.05)$. Fatty acids were dominated by 14:0, 16:0, 16:1(n-7), 18:1(n-7) and 20:5(n-3) (Table 3). Amounts of 18:4 and 18:2(n-6) were elevated on the upper mudflat at Site CF during win- ter, spring and summer relative to autumn at this site and also all the other sites sampled over the course of the year. The uncommon fatty acids 15:0 and 17:1(n-8) comprised an unusually high proportion of the fatty acids on both mudflats at times (Table 3), most notably during autumn at Site CF. These 2 fatty acids were also highly correlated $(r=0.97)$, suggesting that they arose from the same source.

Compound-specific stable-isotope analysis. The fatty acids 22:0, 24:0 and 26:0 were the most depleted in ${ }^{13} \mathrm{C}$, with the $\delta^{13} \mathrm{C}$ of these fatty acids ranging between -26.0 and $-31.4 \%$ (Table 4 ). The $\mathrm{C}_{19}$ polyunsaturated fatty acid (PUFA) was consistently the most enriched of the fatty acids, with the $\delta^{13} \mathrm{C}$ of this fatty acid ranging between -12.3 and $-13.9 \%$. The branched 15:0 and 15:1 fatty acids were not sufficiently resolved from each other to allow their individual $\delta^{13} \mathrm{C}$ values to be measured, and the value of the composite of all 3 is presented. The $\delta^{13} \mathrm{C}$ of these bacterial fatty acids were heaviest at Site $\mathrm{CF}$ and lightest at Site PC, and were 1 to $4 \%$ lighter than the bulk $\delta^{13} \mathrm{C}$ of the separated MPB obtained at each of the respective sites.

Biomarkers in separated microphytobenthos. Microscopic examination of the MPB which had been sepa- 

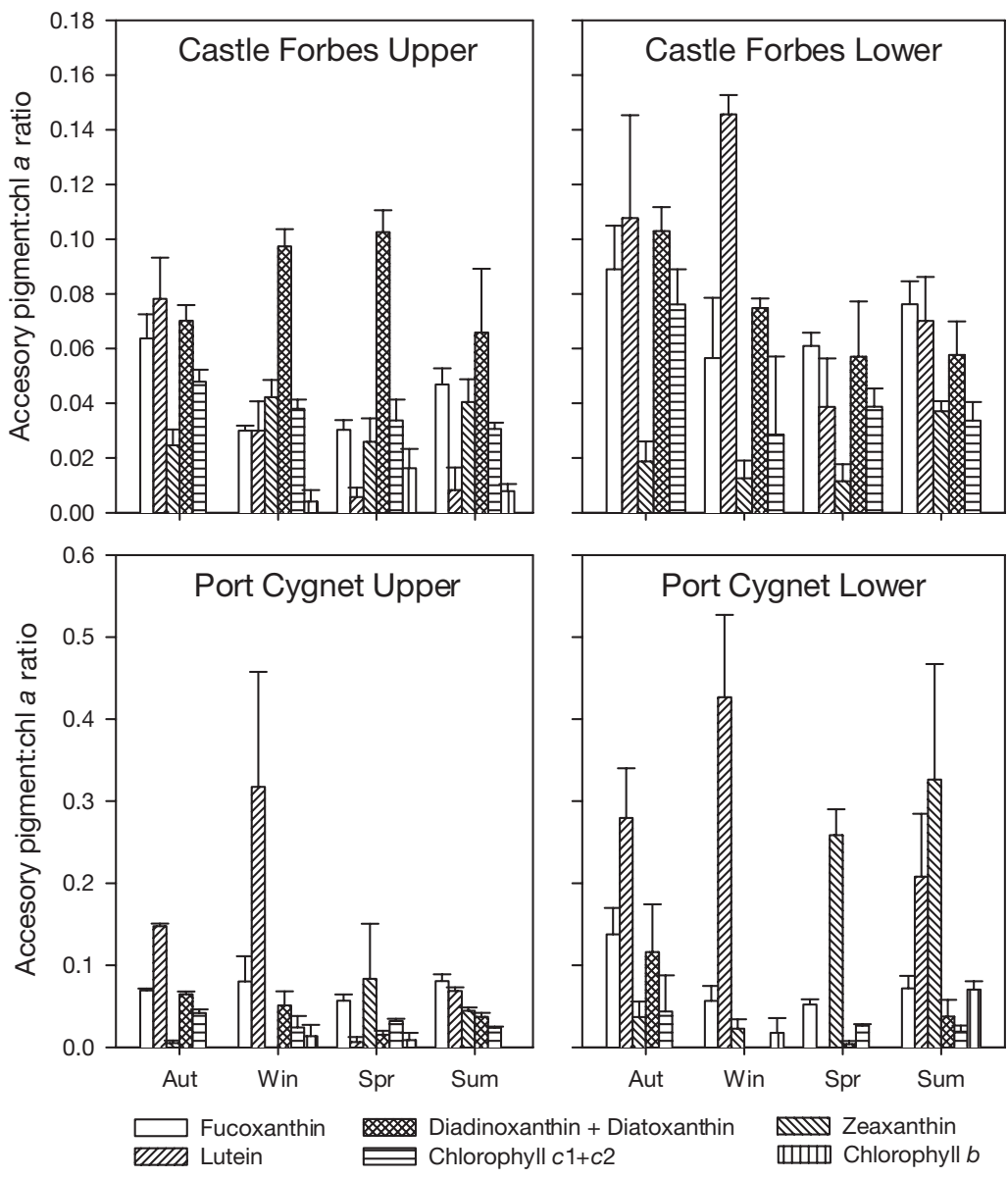

Fig. 2. Accessory pigment:chl a ratios of major pigments detected in top $0.5 \mathrm{~cm}$ of sediment in autumn (Aut), winter (Win), spring (Spr) and summer (Sum) on upper and lower mudflats of the 2 study sites in 2001. Error bars: $\mathrm{SE}$ of mean ( $\mathrm{n}=3$ to 4$)$

rated from the sediment using the lens-tissue method consistently showed that cyanobacteria were the dominant taxa present. A typical image of the MPB after separation from the sediments is shown in Fig. 4a. The dominant cyanobacteria were identified to genus level and comprised 1 or more species of Oscillatoria (referred to as Oscillatoria spp. henceforth); Spirulina sp. was also observed, but at a much lower relative abundance.

Sterols and hopanoid alcohols were below detection levels in the separated sample of MPB. The major fatty acid present was $16: 0$, which comprised $50 \%$ of the total fatty acids; the other major fatty acids found in the microalgae were 18:4 (23\%) and 18:3 (15\%) (Table 5). The carbon:chl a ratio in the separate MPB fraction from the upper mudflat at Site CF in July 2000 was 19.0 .

A summary of the relative proportion of accessory pigments (pigment:chl a ratio) in the MPB from intact cores, the lens-tissue separated fraction and the frac- tion remaining after separation are shown in Fig. 4b. The algal fraction separated using the lens-tissue method showed a significant enrichment in the proportion of zeaxanthin (relative to chl a) compared to the algal fraction remaining within the sediment (Student's $t$-test, $\mathrm{p}<0.01$ ) as well as the total algal fraction extracted from intact cores ( $t$-test, $\mathrm{p}<0.01)$. Conversely, the relative proportions of lutein, chl $c$ and diadinoxanthin to chl a were all significantly less in the lens-tissue separated fraction than the whole and the remaining fractions $(t$-test, $\mathrm{p}<0.05)$. The relative proportion of fucoxanthin to chl a was significantly less in the separated fraction than in the remaining fraction ( $t$-test, $\mathrm{p}<0.01$ ), but not significantly different from that in the total algal fraction ( $t$-test, $\mathrm{p}>0.05)$.

\section{DISCUSSION}

\section{Fractionation of MPB using the lens-tissue method}

The pigment data presented here clearly show that the lens-tissue method fractionated the MPB, as evidenced by the significant changes in the ratios of accessory pigments to chl a (Fig. 4b). The increase in the zea:chl a ratios indicates that the cyanobacterial component of the MPB became enriched (Jeffrey \& Vesk 1997). The decrease in each of chl $c$, fucoxanthin, diadinoxanthin, lutein and chl $b$ relative to chl $a$ indicates that the diatom and green algal components of the MPB were discriminated against (Jeffrey \& Vesk 1997). Biomarker analysis of the separated algal fraction further suggested that a significant fractionation of the MPB occurred using the lens-tissue method. Diatom markers, including the PUFA 20:5(n-3) and sterol 24-methylcholesta-5, 22E-dien-3 $\beta$-ol, were not detected at all (Table 5), nor were the green algae fatty acid markers including 18:2(n-6) and 18:1(n-9) (Volkman et al. 1989, 1998). These markers were all detected in the sediments throughout the year, further indicating that the separated fraction of MPB was depleted in diatoms and chlorophytes compared to that remaining within the sediment. Visual observations of the sediments at Site CF were also in agreement with the biomarkers, with cyanobacteria dominating the lens-tissue extracted fraction of the MPB (Fig. 4a). 


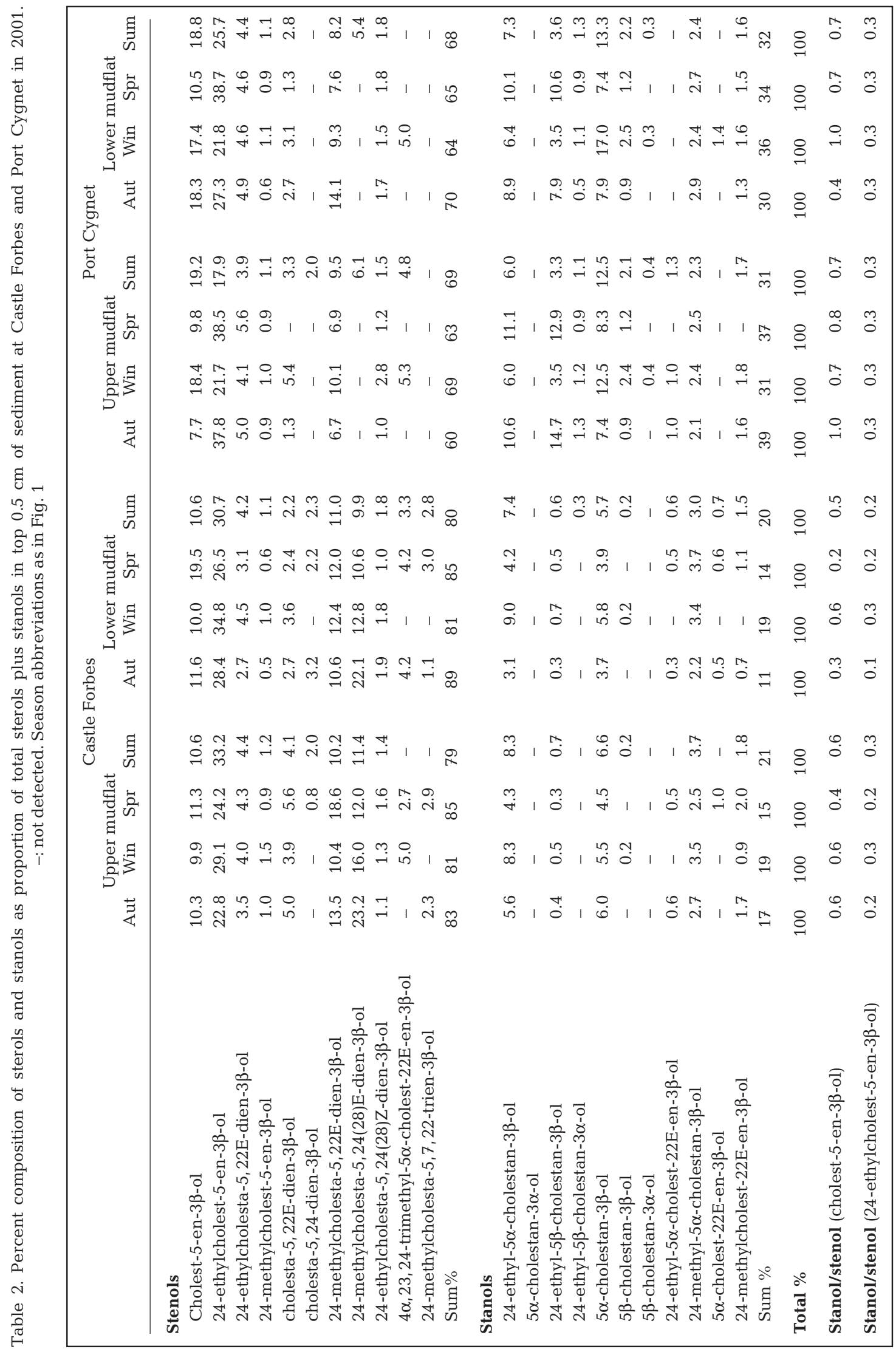



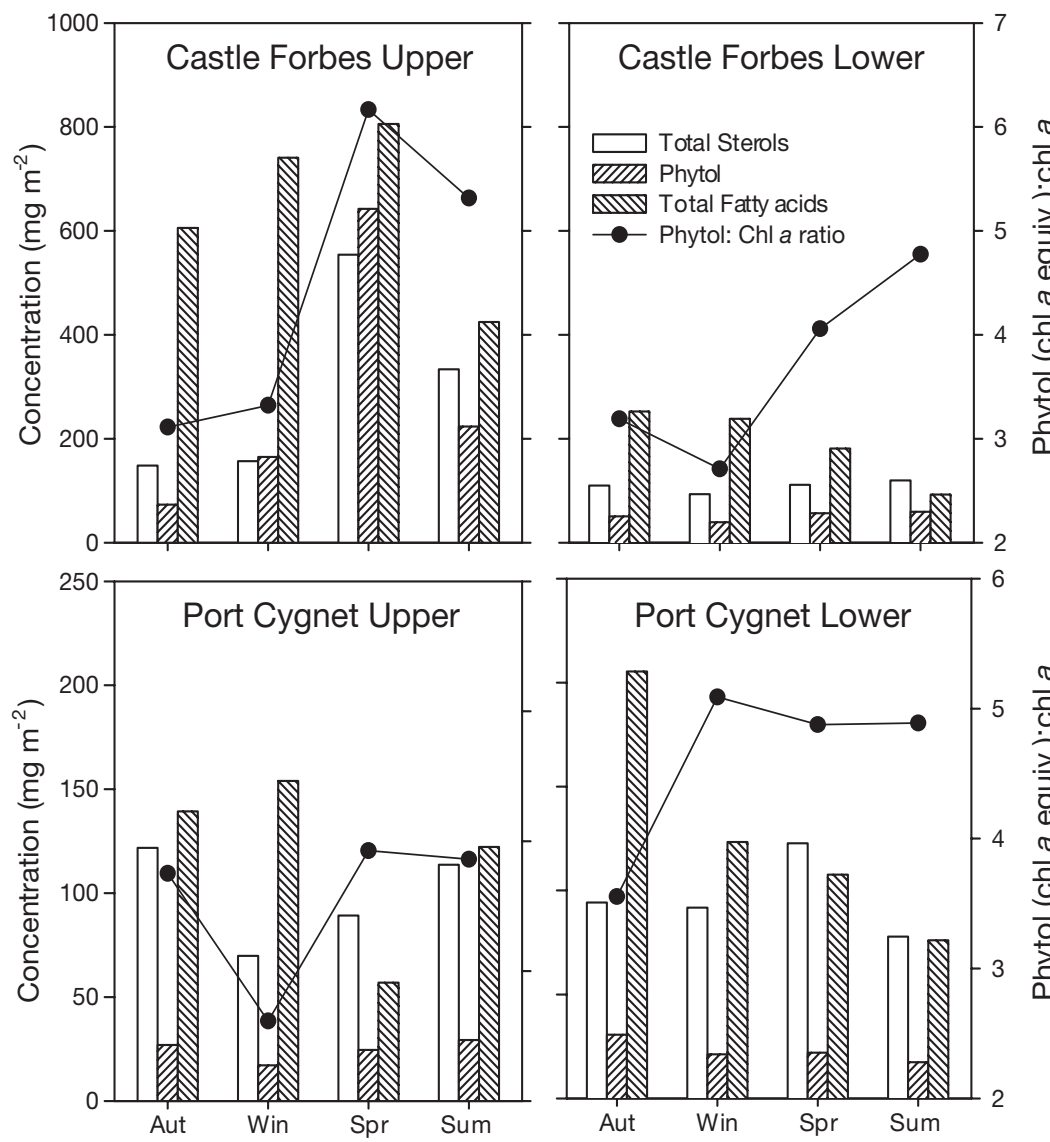

Fig. 3. Total sterols, total fatty acids and phytol, and the phytol:chlorophyll a ratio measured in top $0.5 \mathrm{~cm}$ of sediment in autumn (Aut), winter (Win), spring (Spr) and summer (Sum) on upper and lower mudflats of the 2 study sites in $2001(\mathrm{n}=1)$
The depletion of diatoms in the epipelic fraction of the MPB is somewhat surprising as diatoms are generally regarded as the most motile fraction of MPB communities, particularly in intertidal sediments (e.g. de Jonge 1980, Dalsgaard et al. 2000). The enriched cyanobacterial fraction was dominated by Oscillatoria spp., which are known to be highly mobile in cyanobacterial mats (Stal 1995). In a hot-spring microbial mat, O. terebriformis was found to move to the surface of the sediment in the morning, move back into the sediment during the middle of the day, return to the surface in the afternoon, and move back into the sediment at night (Stal 1995). The motility of Oscillatoria spp. was also noted by Eaton \& Moss (1966), who observed that virtually all of the trichomes migrated out of the sediment onto a coverglass. The data presented here clearly show that the lens-tissue method will fractionate the MPB in favour of the most motile algal species, which in this instance were cyanobacteria dominated by Oscillatoria spp. This finding is significant, as many studies on the stable isotopic composition of MPB use this method to separate MPB from the sediment, for example (Couch 1989, Riera 1998).
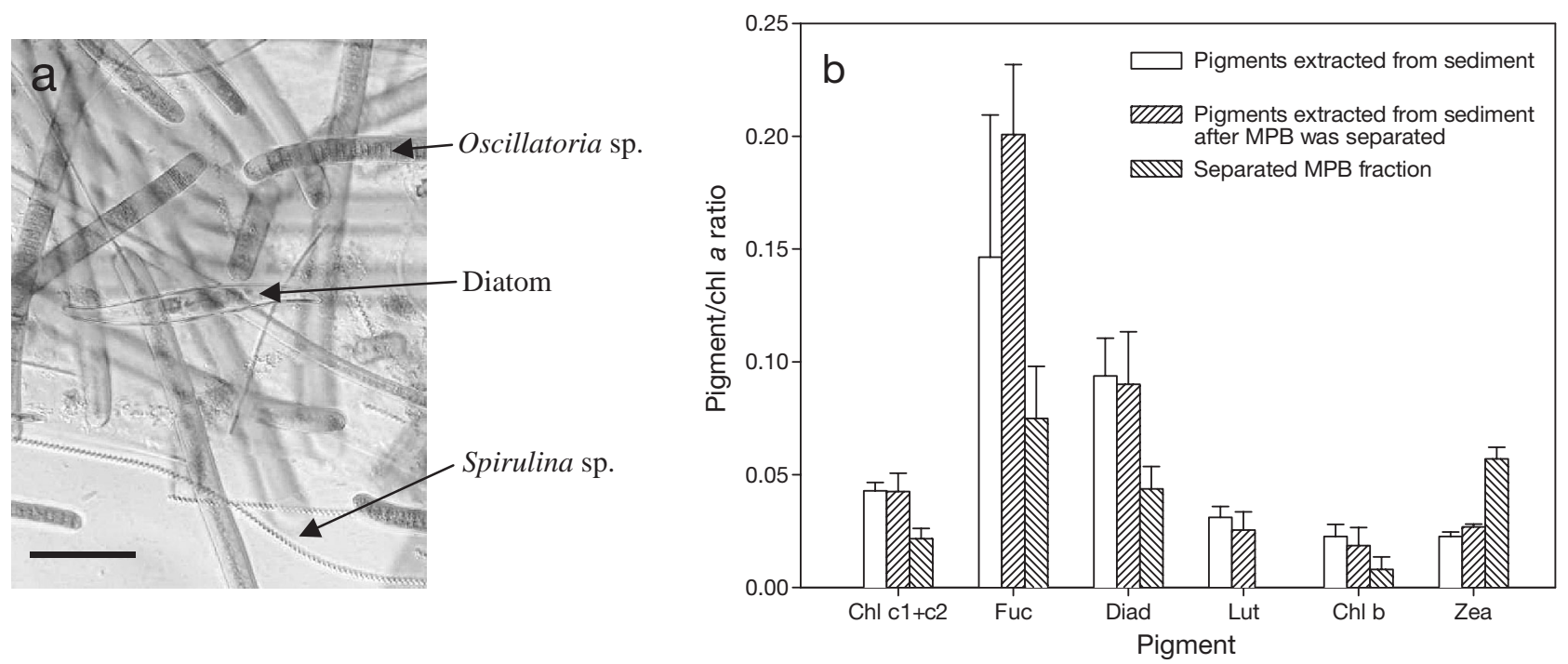

Fig. 4. (a) Image of microphytobenthos (MPB) separated from sediment using 'lens-tissue' method, showing organisms identified as Oscillatoria spp., Spirulina sp. and a diatom (February 2002; scale bar $=50 \mu \mathrm{m}$ ). (b) Pigment-to-chl a ratios of accessory pigments chl $c_{1}$ and $c_{2}$, fucoxanthin, diadinoxanthin, lutein, chl $b$ and zeaxanthin in sediment extracts, sediment extracts after MPB had been separated, and in extracts of separated MPB fraction. Samples taken in August 2001. For abbreviations of carotenoids, see 'Biomarkers' sub-section in 'Results' 


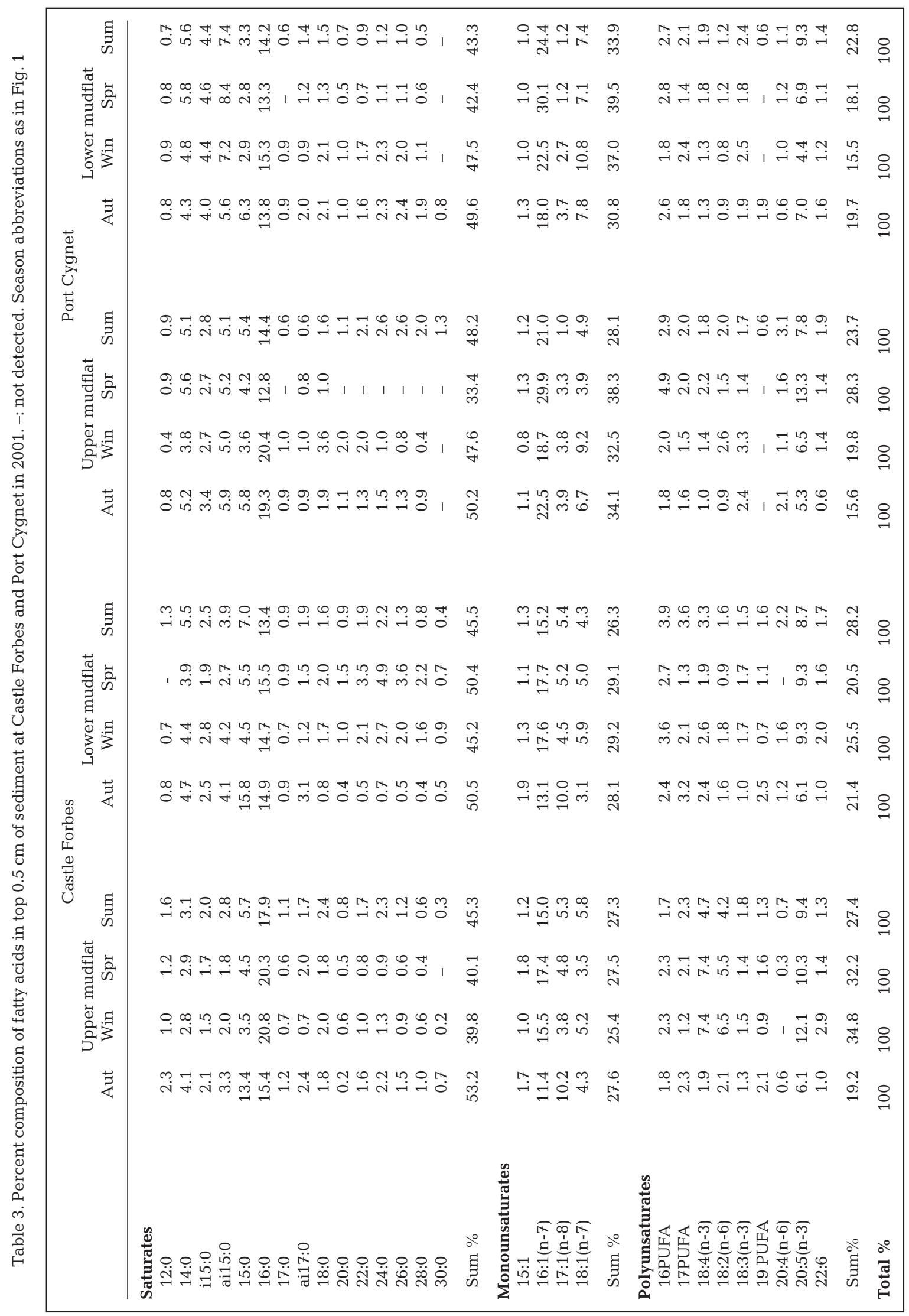


Table $4 . \delta^{13} \mathrm{C}(\%)$ of lipid biomarkers extracted from sediments collected from Port Cygnet (PC) and Castle Forbes Bay (CF) in autumn (Aut) and spring (Spr)

\begin{tabular}{|lcccc|}
\hline \multirow{2}{*}{ Fatty acid } & \multicolumn{2}{c}{ CF } & \multicolumn{2}{c|}{ PC } \\
& \multicolumn{2}{c}{ Upper mudflat } & \multicolumn{2}{c}{ Upper mudflat Lower mudflat } \\
& Aut & Spr & Aut & Aut \\
\hline 14:0 & -21.0 & -17.5 & -23.4 & -23.4 \\
i/ai $15: 0+15: 1$ & -18.7 & -16.1 & -22.7 & -21.1 \\
15:0 & -14.4 & -13.7 & -15.4 & -13.4 \\
16:1(n-7) & -18.4 & -21.2 & -18.8 & -22.8 \\
16:0 & -18.0 & -15.9 & -21.6 & -22.0 \\
18:4 & -16.9 & -15.5 & & \\
18:1+18:2+18:3 & -23.9 & -19.1 & -24.5 & -25.6 \\
18:0 & -24.1 & -19.8 & -26.4 & -25.0 \\
19 PUFA & -13.9 & -12.3 & & -12.4 \\
20:5(n-3) & -18.9 & -18.5 & -17.8 & -15.0 \\
20:0 & & & -26.8 & -24.9 \\
22:6 & -19.4 & -14.9 & -28.7 & -21.2 \\
22:0 & -26.4 & -26.0 & -28.2 & \\
$24: 0$ & -29.6 & -27.4 & -28.4 & -27.6 \\
$26: 0$ & -31.1 & -28.9 & -30.6 & -31.4 \\
\hline
\end{tabular}

\section{Lipids and pigments as indicators of MPB taxonomy}

Most studies of MPB on estuarine mudflats report a predominance of diatoms (Cariou-Le Gall \& Blanchard 1995, Barranguet et al. 1997, Brotas \& Plante-Cuny 1998, Lucas \& Holligan 1999, Cahoon \& Safi 2002). In these studies, relatively high concentrations of fucoxanthin have revealed a dominance of diatoms with fuc:chl a ratios of between 0.35 and 1.6 being observed. In the Huon Estuary mudflats, the observed fuc:chl a ratios were very much lower, generally being less than 0.1 . The accessory pigments lutein and zeaxanthin were also present in comparable or greater quantities, indicating that chlorophytes and cyanobacteria were also present (Jeffrey \& Vesk 1997) (Fig. 2). The presence of chlorophytes and cyanobacteria has also been recorded in other MPB communities (Cahoon 1999), including intertidal sediments (Barranguet et al. 1997, Brotas \& Plante-Cuny 1998). During spring at Site $\mathrm{CF}_{\text {, the }}$ xanthophyte Vaucheria sp. was observed, but no pigments characteristic of the Xanthophyceae were detected.

The lipid biomarker data were generally in broad agreement with the pigment data. The presence of diatoms at all sites and all times of the year was indicated by the fatty acids 20:5(n-3), 24-methylcholesta-5,22Edien-3 $\beta$-ol, as well as 24-methylcholesta-5, 24(28)-dien$3 \beta$-ol which has recently been suggested as a marker for diatoms (Volkman et al. 1998). 24-methylcholesta$5,24(28)$-dien-3 $\beta$-ol is also produced by some dinoflagellates and prasinophytes (Volkman et al. 1998), but the xanthophyll pigments peridinin and prasinoxanthinparticular to each of these groups, respectively (Jeffrey \& Vesk 1997) - were not detected. 4 $\alpha$,23, 24-trimethyl-5 $\alpha$ -
cholest-22E-en-3 $\beta$-ol, which is specific to dinoflagellates, was also only detected occasionally and in relatively small quantities. Therefore, it would appear that in this system 24-methylcholesta-5, 24(28)-dien-3 $\beta$-ol is likely to arise mostly from diatoms. The presence of chlorophytes was indicated by the fatty acids 18:2(n-6) and 18:3(n-3) (Volkman et al. 1980, 1989), particularly at Site PC, where the pigment data suggested these algae were generally dominant. Although there are no generally accepted fatty acid markers for cyanobacteria, the 18:4 PUFA was present in relatively high proportions in the extract of separated MPB dominated by cyanobacteria. (Table 5). While hopanoid alcohols were detected within the sediment (data not shown) they were apparently not derived from the dominant species of cyanobacteria, since no hopanoid alcohols were detected in the separated MPB extract. This is consistent with the data of Summons et al. (1999), which showed that a number of species of Oscillatoria (the dominant genus in the separated fraction of MPB) are among the few cyanobacteria that do not produce hopanols.

A quantitative estimate of the relative proportions of algal classes is difficult to make using accessory pigments, as the ratio to chl a can be highly variable and there are no published data on accessory pigment ratios

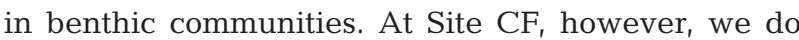
have an estimate of the zea:chl a ratio for Oscillatoria spp. (0.06) based on the lens-tissue study. This ratio was applied to the zeaxanthin concentrations measured at Site CF to obtain an estimate of the percent contribution to chl a by Oscillatoria spp. (Table 6). We also made the same estimate using the fatty acid 18:4 which was found to be a major fatty acid component of the separated Oscillatoria spp. and had a measured ratio to chl a of 0.3 (Table 5). It was assumed that the contribution of 18:4 by chlorophytes (which are known to produce $\mathrm{C}_{18}$

Table 5. Percent composition of fatty acids and ratio of fatty acid 18:4 to chl a equivalents of phytol in benthic microalgae separated from sediment using the lens-tissue technique. Sample collected from upper mudflat at Castle Forbes Bay in January 2002

\begin{tabular}{|lc|}
\hline Fatty acid & \% composition \\
\hline $14: 0$ & 1.6 \\
$16: 1(\mathrm{n}-7)$ & 5.8 \\
$16: 0$ & 50.7 \\
$18: 4(\mathrm{n}-3)$ & 23.3 \\
$18: 3(\mathrm{n}-3)$ & 15.8 \\
$18: 0$ & 2.7 \\
Total & 100.0 \\
$18: 4 /$ phytol (chl a equiv.) & 0.3 \\
\hline
\end{tabular}


Table 6. Oscillatoria spp. Percent contribution to total chl a calculated using zeaxanthin and fatty acid 18:4, at Castle Forbes Bay in autumn, winter, spring and summer

\begin{tabular}{|c|c|c|}
\hline Season & $\begin{array}{l}\% \text { contribution } \\
\text { zeaxanthin }\end{array}$ & $\begin{array}{l}\text { a estimated from: } \\
\text { fatty acid } 18: 4\end{array}$ \\
\hline \multicolumn{3}{|c|}{ Upper mudflat } \\
\hline Autumn & 41 & 51 \\
\hline Winter & 70 & 111 \\
\hline Spring & 43 & 58 \\
\hline Summer & 67 & 48 \\
\hline \multicolumn{3}{|c|}{ Lower mudflat } \\
\hline Autumn & 31 & 39 \\
\hline Winter & 21 & 43 \\
\hline Spring & 19 & 25 \\
\hline Summer & 62 & 25 \\
\hline
\end{tabular}

PUFAs) was negligible, since previous studies have shown that chlorophytes only produce small amounts of 18:4 compared to total lipids ( $3 \%$ ) (Volkman et al. 1989, Ahlgren et al. 1992). These 2 approaches were generally in broad agreement (Table 6), suggesting that Oscillatoria spp. made a contribution of between 20 and $100 \%$ to the chl $a$ in the upper and lower mudflats over the course of the year at Site CF.

\section{Lipid biomarkers as indicators of sources of organic carbon within sediments}

To estimate the relative contributions of different organic matter sources to the sediments, fatty acid data are separated into algal, terrestrial plant, aquatic macrophyte and bacterial markers (Volkman et al. 1980, Canuel \& Martens 1993, Shi et al. 2001, Wilson et al. 2001). Here, we have used an a posteriori approach to group the major sources of fatty acids. Cluster analysis of the normalised (raw data - mean/standard deviation) fatty acid and chl a data showed that the fatty acids could be broken down into 3 major groups (Fig. 5). These groups of fatty acids were assigned sources (see following paragraphs), and the fatty acids in each group were then summed to obtain an estimate of total fatty acids derived from each source.

The first group consisted of chl a as well as established algal markers comprising 20:5(n-3), 16:1(n-7) and the PUFA 18:4, which was found to be the major fatty acid in algae separated from the sediment. This strongly suggests that this cluster represented fatty acids derived from a mixed community of MPB. The fact that the fatty acid 18:1(n-7) clustered on the periphery of the microalgal fatty acids suggests that it is produced by both bacteria and microalgae, as found in other studies, e.g. Volkman et al. (1980). The PUFA 22:6(n-3) was also clustered on the periphery of the algal markers, most probably reflecting the fact that this fatty acid is produced by both microalgae (Volkman et al. 1989) and sediment infauna (Kharlamenko et al. 2001).

The second cluster of fatty acids consisted predominantly of odd-chain fatty acids including the widely used bacterial markers i15:0 and ai15:0 (Findlay \& Dobbs 1993), strongly suggesting that the fatty acids within this group were predominantly derived from bacterial sources. The unusual fatty acids 15:0 and $17: 1(n-8)$ were present in high relative proportions at

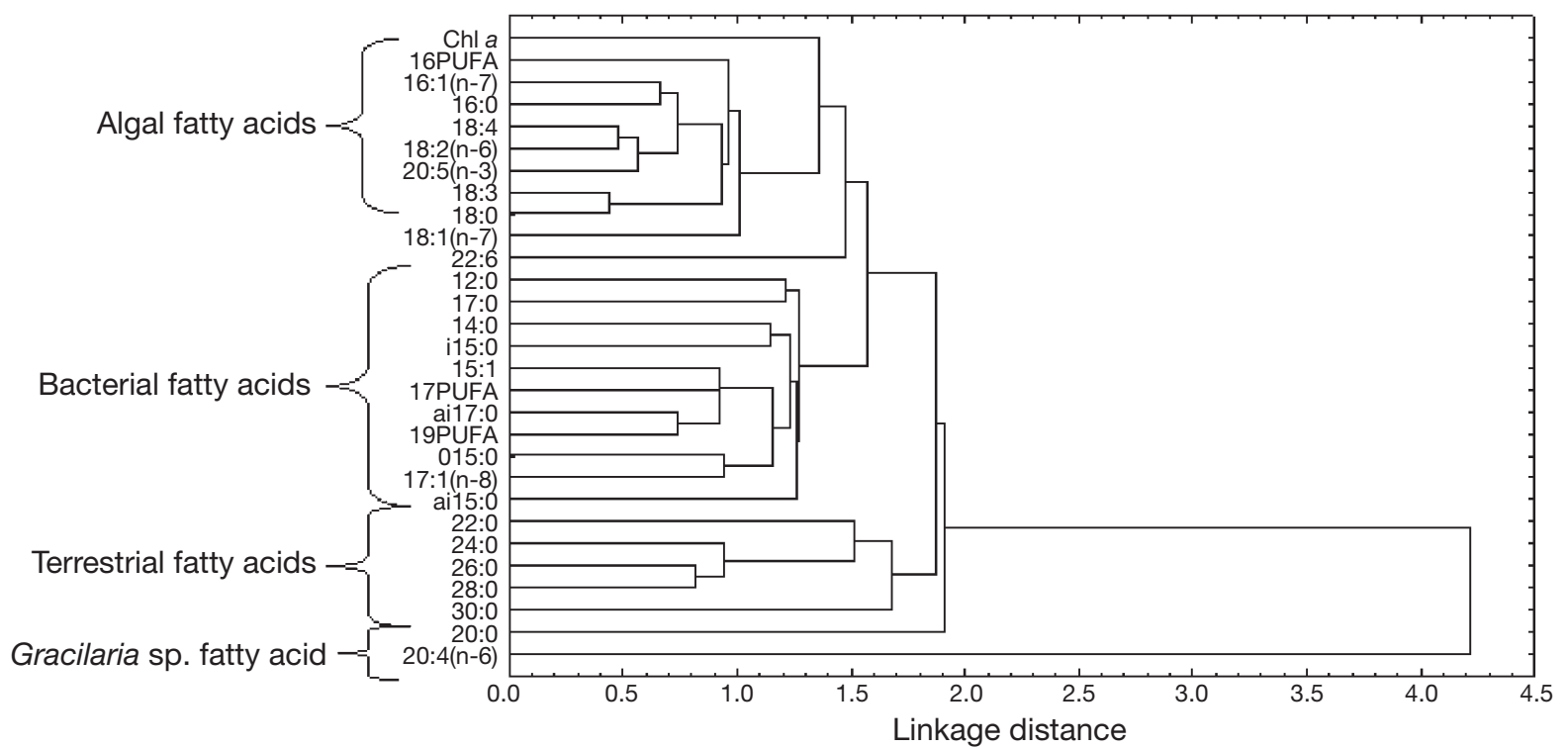

Fig. 5. Cluster analysis (Euclidean distances) of all normalised fatty acid data pooled from Castle Forbes Bay and Port Cygnet over study period $(\mathrm{n}=16)$. Data clustered into groups, defined as being derived from algal, bacterial, terrestrial or macroalgal sources (see 'lipid biomarkers as indicators of sources of organic carbon within sediments' subsection in 'Discussion' for details) 
Castle Forbes Upper

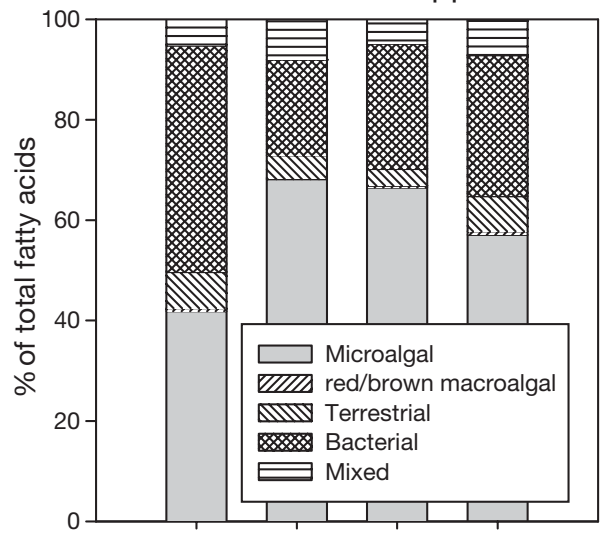

Port Cygnet Upper

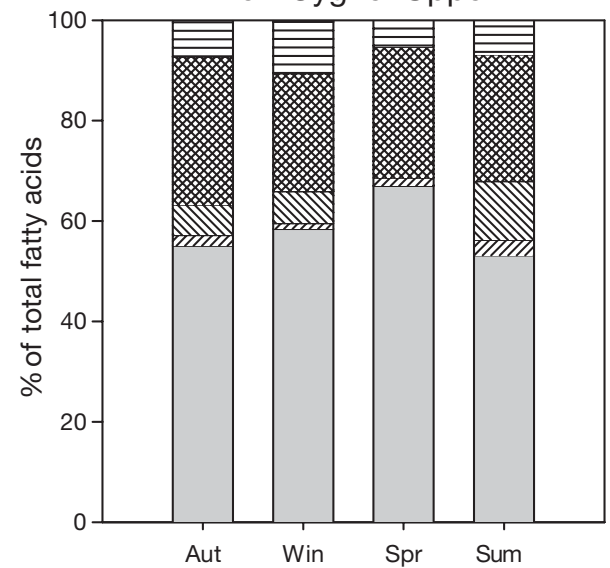

Castle Forbes Lower

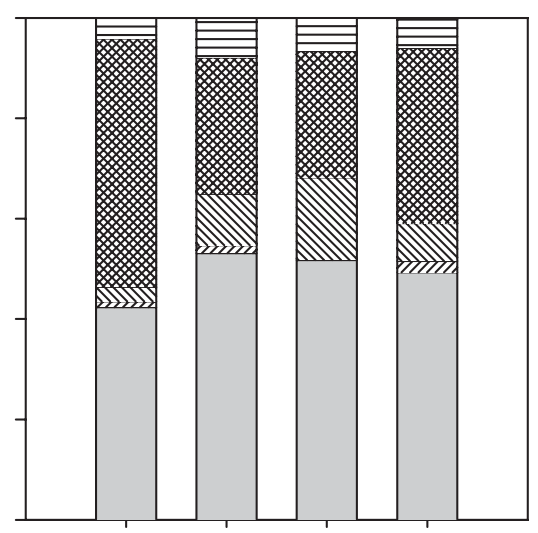

Port Cygnet Lower

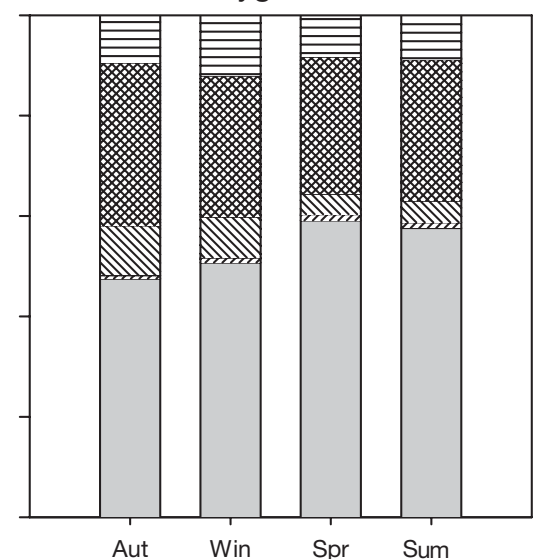

Fig. 6. Relative proportions of fatty acids derived from algal, bacterial, terrestrial, mixed or macroalgal sources, in autumn (Aut), winter (Win), spring (Spr) and summer (Sum) at the 2 study sites in 2001. Grouping of sources of these fatty acids was carried out using cluster analysis, as shown in Fig. 5

The proportion of fatty acids derived from microalgal sources dominated relative to other sources on both mudflats throughout the year, generally comprising around $50 \%$ of the total fatty acids (Fig. 6). The high proportion of PUFAs within the algal fatty acids (Table 4) indicates that living cells from the MPB are likely to be a major source of labile organic carbon to the sediments. The relative proportions of bacterial fatty acids were greatest (up to $50 \%$ of total fatty acids) during the warmest sampling periods of summer and autumn at Site CF. A similar seasonal variation in bacterial fatty acids was not so noticeable at Site PC. Canuel \& Martens (1993) also observed that the relative contribution of organic carbon from bacteria dropped during winter and peaked during the warmer summer months when sediment respiration rates (as indicated by sulphate reduction) were highest. Consistent with this, we observed a significant relationship between sediment respiration rates and total bacterial fatty acids $(\mathrm{r}=0.7, \mathrm{p}<0.01)$. Algal fatty acids became relatively more abundant compared to bacterial fatty acids during the colder sampling periods in winter and spring. This relative increase in algal fatty acids during cooler periods is consistent with previous observations that bacterial metabolism is reduced to a

times, and were closely clustered, suggesting a common source within the microbial fatty acids, or that they are derived from an organism that consumes bacteria.

The third cluster of fatty acids contained long-chain fatty acids which are generally indicative of higher plants, suggesting that this group was derived from terrestrial sources (Wannigama et al. 1981). The PUFA 20:4(n-6) was grouped on its own and was, therefore, apparently derived from a different source. Red and brown macroalgae are known to produce 20:4(n-6) in significant quantities, in particular the red alga Gracilaria sp., in which 20:4(n-6) can account for $50 \%$ of the total fatty acids (Vaskovsky et al. 1996). As a Gracilaria sp. was observed to cover up to $50 \%$ of the mudflat at Site PC, it seems probable that the 20:4(n-6) was derived from this macroalga, but it is interesting that the amounts of 20:4(n-6) in the sediments were always quite low. In this study, the clustering of the fatty acids 18:1(n-7) and 22:6 suggested mixed sources. greater extent than that of algae during the colder months, both at this site (Cook et al. 2004a) and elsewhere (Davis \& MacIntyre 1983, Grant 1986, Kristensen 1993).

\section{Stable isotopes as indicators of sources of organic carbon within sediments}

It can be seen from Fig. 7 that 2 end-members are clearly established using carbon stable-isotope values. Terrestrial sediments from the Huon River and smaller creeks as well as plant detritus had a depleted carbon isotopic signature, with a $\delta^{13} \mathrm{C}$ of between -27 and $-29 \%$. Another potential source of organic matter, which we have considered as terrestrial, was the marsh reed Juncus kraussi, which formed large stands on the edges of both mudflats. The data presented here for this species represents a composite for live, standing dead and detrital plant material. The $\delta^{13} \mathrm{C}$ 


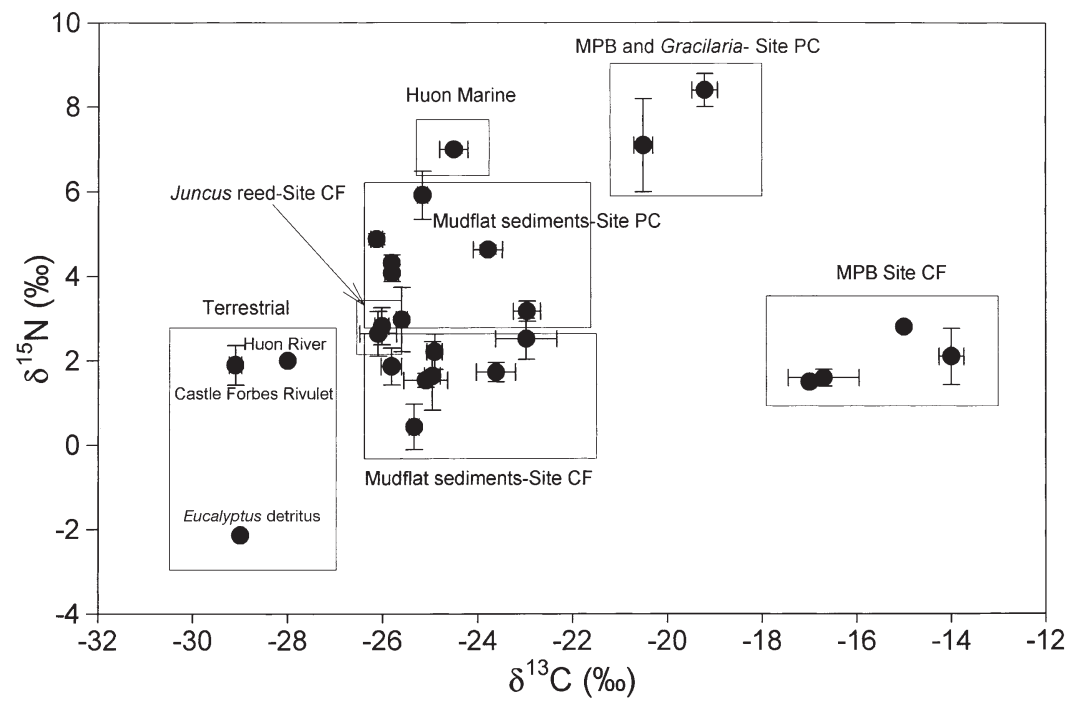

Fig. 7. Dual-isotope plot of $\delta^{15} \mathrm{~N}$ versus $\delta^{13} \mathrm{C}$ for sediment samples taken from Castle Forbes Bay and Port Cygnet over study period in relation to potential sources of organic matter in the sediments (outlined in Table 1) at each site. Error bars $=\mathrm{SE}$ of mean $(\mathrm{n}=3$ to 4$)$. Juncus $=J$. kraussi; Gracilaria = Gracilaria sp.; Eucalyptus = Eucalyptus sp.

value of this was $-26 \%$, which is slightly more enriched in ${ }^{13} \mathrm{C}$ than the other terrestrial sources of organic matter. In contrast, organic carbon derived from estuarine sources including MPB and macroalgae consistently showed a much greater relative enrichment in ${ }^{13} \mathrm{C}$, with $\delta^{13} \mathrm{C}$ values being 'heavier' than $-20 \%$. At Site CF, the MPB was particularly enriched, with $\delta^{13} \mathrm{C}$ values of around $-15 \%$ observed. The heavy $\delta^{13} \mathrm{C}$ values observed at Site $\mathrm{CF}$ are consistent with previous studies of the isotopic signature of MPB, in particular where cyanobacteria make a significant contribution to the algal community (Currin et al. 1995 and references therein), as was the case here.

Signatures of the stable isotopes of nitrogen also allowed a distinction between marine and terrestrial sources of organic matter at Site PC. MPB and macroalgae at this site both exhibited an enrichment in ${ }^{15} \mathrm{~N}\left(\delta^{15} \mathrm{~N}=7\right.$ to $8 \%$ ) compared to terrestrially derived organic matter which was relatively depleted in ${ }^{15} \mathrm{~N}$ $\left(\delta^{15} \mathrm{~N}=-2\right.$ to $2 \%$ ). At Site $C F$, however, the $\delta^{15} \mathrm{~N}$ isotopic signature of MPB was less than $3 \%$, and indistinguishable from that of organic matter derived from terrestrial sources. Low $\delta^{15} \mathrm{~N}$ values in benthic and pelagic algae are most likely to arise from nitrogen fixation by cyanobacteria (Currin et al. 1995, MacGregor et al. 2001). This accords with the high rates of $\mathrm{N}_{2}$ fixation observed here at times (Cook et al. 2004b). The $\delta^{15} \mathrm{~N}$ of $7.1 \%$ for the MPB at Site PC was much more enriched than at Site $\mathrm{CF}$, reflecting the abundance of diatoms at this site and lower rates of $\mathrm{N}_{2}$ fixation (Cook et al. 2004b). The $\delta^{15} \mathrm{~N}$ of the diatoms, measured at Port
Cygnet, is in the upper range of $\delta^{15} \mathrm{~N}$ literature values reported for benthic diatoms (Riera 1998 and references therein). The high $\delta^{15} \mathrm{~N}$ values of MPB were most probably caused by the drawdown of $\mathrm{NO}_{3}{ }^{-}$within the Huon Estuary over the summer months (Butler et al. 2000), which resulted in a greater uptake of ${ }^{15} \mathrm{NO}_{3}{ }^{-}$by microalgae due to Rayleigh fractionation (Rau et al. 1998).

The isotopic end-members described above are qualitatively similar to those observed elsewhere (Heip et al. 1995 and references therein), where carbon and nitrogen are isotopically enriched at the marine endmember of the estuary compared to the riverine end-member. In a study of the Tay Estuary, Thornton \& McManus (1994) compared the use of $\mathrm{C}: \mathrm{N}$ ratios, $\delta^{13} \mathrm{C}$ and $\delta^{15} \mathrm{~N}$ as tracers of marine and terrigenous organic matter. They concluded that $\delta^{13} \mathrm{C}$ provided the best means of estimating the relative contribution of organic matter arising from marine and terrestrial sources because the isotopic signature was more likely to be conserved during organic matter degradation, whereas C:N ratios and $\delta^{15} \mathrm{~N}$ are both likely to increase as organic matter is degraded. In our study, the isotopic signature of carbon gave a much clearer separation of the marine and terrestrial end-members than the nitrogen isotope data, and it was used to estimate the relative contribution of terrestrial and marine organic matter to the sediments. Assuming a simple 2-component mixing system, the fraction of terrigenous organic matter to the total pool in the sediment can be estimated using the mixing equation of Schultz \& Calder (1976):

$$
F_{t}=\frac{\delta^{13} C_{s}-\delta^{13} C_{m}}{\delta^{13} C_{t}-\delta^{13} C_{m}}
$$

where $F$ is the fraction of organic matter in the sample and the subscripts $\mathrm{s}, \mathrm{t}$ and $\mathrm{m}$ denote sample, terrigenous and marine.

At Site CF, the isotopic signature of MPB was defined as 1 end-member with a $\delta^{13} \mathrm{C}$ value of $-15 \%$. The terrestrial end-member at this site was considered likely to consist of a mixture of the reed Juncus kraussi and terrestrial organic matter, so a mean $\delta^{13} \mathrm{C}$ value of $-27 \%$ was assumed. At Site PC, the algal end-member was assumed to consist of MPB and Gracilaria sp., and a mean $\delta^{13} \mathrm{C}$ of $-20 \%$ was assumed. A terrestrial $\delta^{13} \mathrm{C}$ value of $-27 \%$ was used at Site PC; this was measured in sediment taken from Agnes Rivulet, which discharges into Port Cygnet. The end-members defined in this manner are also consistent with the compound specific analysis of biomarkers from these sediments (Table 4$)$, with the terrestrial derived fatty acids (22:0, 
24:0, 26:0) being depleted in ${ }^{13} \mathrm{C}$ and the algae-derived fatty acids (20:5 n-3, 16:1n-7) being relatively enriched. We have neglected the possible contribution of phytoplankton blooms within the estuary, to these endmembers. We believe this is reasonable given that the blooms are short-lived and that the sterol $(4 \alpha, 23,24$ trimethyl- $5 \alpha$-cholest-22E-en-3 $\beta$-ol; dinosterol) and pigment (peridinin) markers of dinoflagellates that have dominated recent algal blooms within the Huon Estuary (Butler et al. 2000) were not detected in significant quantities.

Organic matter derived from terrestrial sources dominated the organic matter pool in the sediments at all sites, with the exception of the lower mudflat at Site $\mathrm{PC}$, where algal sources of organic matter dominated during autumn (Fig. 8a). C:N ratios in the sediments were generally close to or in excess of 12 , which suggest mixed sources dominated by terrestrial organic matter. Note that terrestrially derived fatty acids make up only a small fraction of total fatty acids, but these comprise a much smaller proportion of the organic carbon pool in higher plants than the fatty acids in MPB and bacteria. For example, Canuel \& Martens (1993) assumed that the long-chain fatty acids comprised $4 \%$ of the extractable lipids and that the extractable lipids comprised $10 \%$ of the total organic carbon in higher plants. For algae, Canuel \& Martens (1993) converted lipids to carbon by assuming that fatty acids accounted for $40 \%$ of their lipid content, and that lipids comprised $20 \%$ of the carbon in these organisms. As an example, the lipid data were converted into carbon derived from algae and terrestrial plants using these ratios for the sediment data from CF upper during autumn. This resulted in an approximately 80:20 split in the carbon from terrestrial and algal sources respectively, which is consistent with the stable isotope data.

The contribution of live MPB biomass to the 'algae'derived organic carbon pool was calculated using the measured carbon-to-chl a ratio of 19 as well as chl a data presented in Cook et al. (2004a). Live MPB generally only comprised less than $20 \%$ of the algal organic

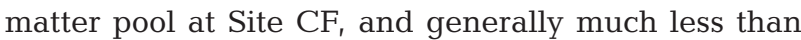
$10 \%$ at Site PC (Fig. 8b). If the 'algal' organic matter was derived from MPB, then the majority of this organic matter was present as detritus from which the chl a had been degraded, or heterotrophic biomass synthesised from carbon derived from MPB. At Site CF, evidence that the majority of MPB-derived carbon occurs as detritus or incorporated into heterotrophic biomass is supplied by the significant correlation between phytol and the algal fraction of organic matter within the sediment $(r=0.72, \mathrm{p}<0.05)$, whereas the correlation between the algal fraction and chl a was much lower and not significant. As a degradation product of chl $a$, phytol provides a more time-integrated measure of recent autotrophic carbon input than chl a.

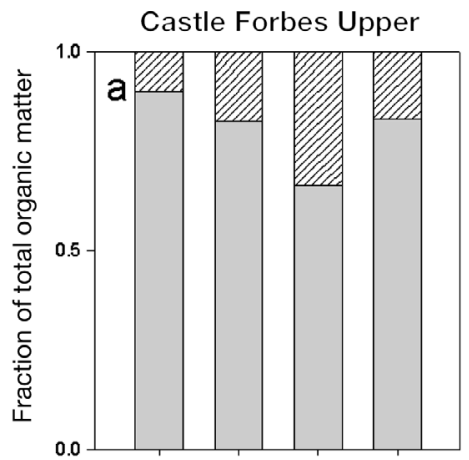

Castle Forbes Lower
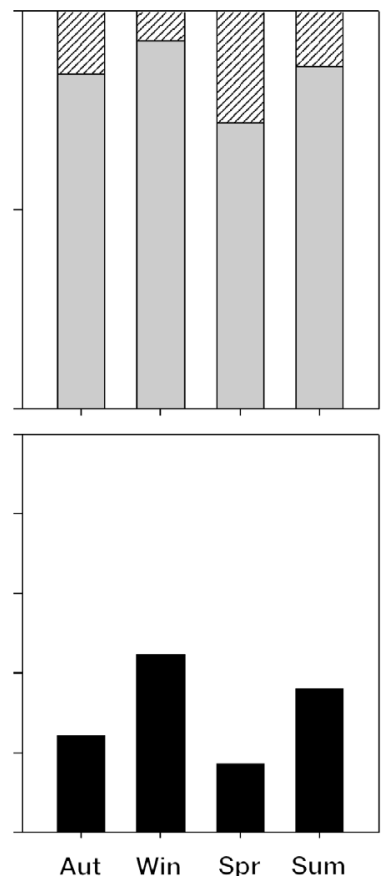

Port Cygnet Upper
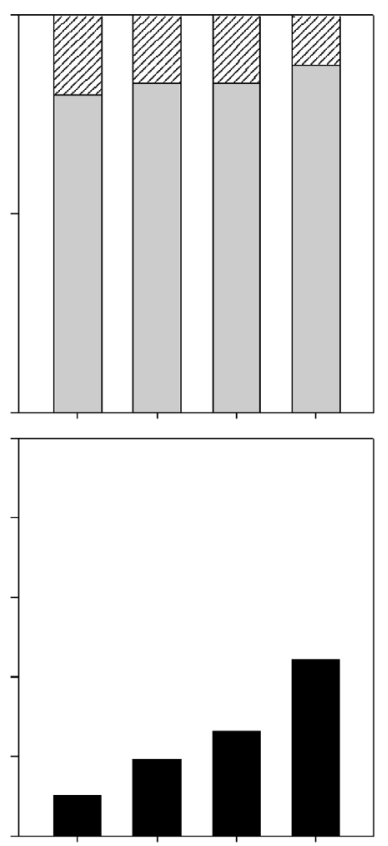

Aut Win Spr Sum
Port Cygnet Lower

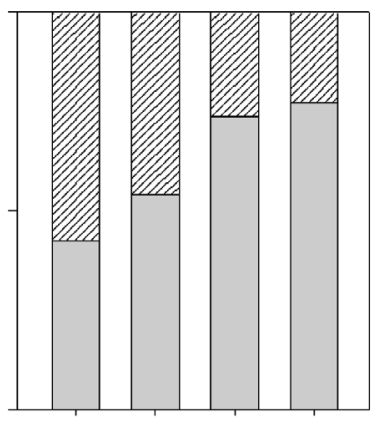

Marine

Terrigenous

Fig. 8. (a) Fraction of organic matter derived from marine and terrestrial sources calculated using carbon stable-isotope ratios; (b) proportion of 'marine' organic pool accounted for by live MPB biomass. Data calculated using chl a data and a carbon:chl a ratio of 19 in autumn (Aut), winter (Win), spring (Spr) and summer (Sum) at the 2 study sites in 2001 
This was manifested at Site $\mathrm{CF}$, with phytol equivalents generally 3 to 6 times in excess of chl a. As such, phytol remains in the sediment as a recent record of senescent algal biomass or that which has been consumed and incorporated into biomass by heterotrophs. Phytol itself is also degraded in sediments, with a recent study showing that 85 to $90 \%$ of phytol will be degraded within 3 mo (Grossi et al. 1998). In contrast, the turnover time for chlorophyll was estimated to be in the order of hours to days based on sediment chl a concentrations and estimated rates of primary production presented in Cook et al. (2004a) which is consistent with published chl a degradation rates in sediments under oxic conditions (Sun et al. 1993). Therefore, the phytol present can be regarded as an integrated measure of algal degradation within the sediments over a period of days to weeks.

At Site PC, there was no significant relationship between phytol or chl $a$ and the 'algal' fraction of organic matter. This most probably arose as a consequence of organic matter and phytol within the sediment being derived from 2 different sources at this site, namely microalgae and macroalgae, thus obscuring any correlation.

\section{Sources of carbon for bacterial metabolism}

Given that bacterial fatty acids comprised a significant proportion of fatty acids and presumably also organic carbon, the question still remains as to the source of the carbon being consumed by these bacteria. The most likely supply of organic carbon to bacteria within the sediment is that derived from the MPB, which have a low $\mathrm{C}: \mathrm{N}$ ratio and also contain high proportions of PUFAs and other labile forms of organic carbon (e.g. Budge et al. 2001). Evidence to support this comes from the significant correlations between specific bacterial and algal fatty acids such as i15:0 and 20:5(n-3) $(r=0.83, p<0.001)$.

Compound specific stable-isotope ratio data also supports this hypothesis. One would normally expect the $\delta^{13} \mathrm{C}$ of the bacterial branched $\mathrm{C}_{15}$ fatty acids to be depleted by about 4 to $6 \%$ relative to the substrate they are consuming (Boschker \& Middelburg 2002). If this is the case here, then our data suggests that the bacteria within the sediment are consuming a substrate with a $\delta^{13} \mathrm{C}$ of ca. -10 to $-15 \%$ at Site CF and ca. -15 to $-19 \%$ at Site PC based on the isotopic composition of the branched 15:0 and 15:1 fatty acids (Table 4). MPB, then, are the most likely source of sub-

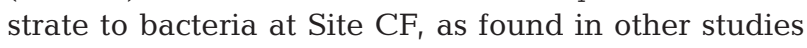
(Canuel et al. 1997, Boschker et al. 1999, 2000, Middelburg et al. 2000). However, at Site PC, the contribution of material derived from Gracilaria sp. cannot be ruled out on the basis of stable-isotope data.
A closer examination of the isotopic signatures of the branched 15:0 and 15:1 fatty acids suggests that the substrate consumed is slightly more enriched than the measured bulk isotopic signatures of the MPB. The most likely explanation for this is that bacteria are consuming a sub-fraction of biomolecules that are isotopically more enriched than the bulk of the algal cells. It has been suggested that bacteria within the sediments rely on extracellular carbohydrates as a substrate (Middelburg et al. 2000), which is isotopically enriched compared to the bulk cellular material (Degens et al. 1968, Moers et al. 1993, van Dongen et al. 2002). The consumption of extracellular carbohydrates by bacteria within the sediment would thus explain the ${ }^{13} \mathrm{C}$ enrichment in the bacterial fatty acids above that expected if they were consuming intact MPB cells.

\section{Summary and conclusions}

The organic matter pool within the sediments was dominated by material from terrestrial sources. This was most probably refractory, and did not undergo remineralisation to any significant extent. Organic matter derived from microalgae made up a minor fraction of the sediment organic matter pool, even though seasonal inputs can be high. This fraction of organic matter is much more labile than that derived from terrestrial sources as indicated by its much lower C:N ratios as well as its high PUFA content. It is the input of this MPB-derived material that drives bacterial production within the sediment, as illustrated by the stable isotope ratios of bacterial fatty acids. Isotope values for individual lipids hold great promise for elucidating food-web interactions and identifying sources of organic matter.

The MPB at Site CF consisted of a mixed community of diatoms, cyanobacteria and chlorophytes. Separation of MPB from the sediment at this site using the lens-tissue technique was found to significantly fractionate the algal community, with cyanobacteria being enriched in the separated fraction. However, the technique was still a useful aid to species identification and for determining biomarker and isotope data for this fraction of the organic matter. Nitrogen fixation was likely to contribute significantly to the growth requirements of cyanobacteria at this site, as indicated by the low $\delta^{15} \mathrm{~N}$ of the cyanobacteria.

Acknowledgements. We thank P. Thompson for useful discussions and critically reading an earlier draft of this manuscript. J. Middelburg, U. Witte and 2 anonymous referees whose thoughtful comments substantially improved an earlier version of this manuscript are also thanked. Thanks also to R. Leeming and K. Berry for assistance with the sterol analysis. D. Frampton, I. Jameson, P. Thompson, H. Forehead and M. 
McCausland all generously provided their expertise in identifying the MPB. A. Bissett, H. Forehead, H. Cook, G. Wilson, K. Phillips and M. Shaw kindly assisted with field work. Financial support from the Coastal and Aquafin CRCs, a Coasts and Clean Seas grant (CCS104/00) and an Australian Postgraduate Association (APA) scholarship for P.L.M.C. are also gratefully acknowledged. This work formed part of a project of the Aquafin $\mathrm{CRC}$, and received funds from the Australian Government's CRCs Program, the Fisheries R\&D Corporation and other CRC Participants.

\section{LITERATURE CITED}

Ahlgren G, Gustafsson IB, Boberg M (1992) Fatty-acid content and chemical composition of fresh-water microalgae. J Phycol 28:37-50

Barranguet C, Herman PMJ, Sinke JJ (1997) Microphytobenthos biomass and community composition studied by pigment biomarkers: importance and fate in the carbon cycle of a tidal flat. J Sea Res 38:59-70

Bautista MF, Paerl HW (1985) Diel $\mathrm{N}_{2}$ fixation in an intertidal marine cyanobacterial mat community. Mar Chem 16: 369-377

Bligh EG, Dyer WJ (1959) A rapid method of total lipid extraction and purification. Can J Biochem Physiol 37:911-917

Boschker HTS, Middelburg JJ (2002) Stable isotopes and biomarkers in microbial ecology. FEMS Microbiol Ecol 40: 85-95

Boschker HTS, de Brouwer JFC, Cappenberg TE (1999) The contribution of macrophyte-derived organic matter to microbial biomass in salt-marsh sediments: stable carbon isotope analysis of microbial biomarkers. Limnol Oceanogr 44:309-319

Boschker HTS, Wielemaker A, Schaub BEM, Holmer M (2000) Limited coupling of macrophyte production and bacterial carbon cycling in the sediments of Zostera spp. meadows. Mar Ecol Prog Ser 203:181-189

Brotas V, Plante-Cuny MR (1998) Spatial and temporal patterns of microphytobenthic taxa of estuarine tidal flats in the Tagus Estuary (Portugal) using pigment analysis by HPLC. Mar Ecol Prog Ser 171:43-57

Budge SM, Parrish CC, McKenzie CH (2001) Fatty acid composition of phytoplankton, settling particulate matter and sediments at a sheltered bivalve aquaculture site. Mar Chem 76:285-303

Butler ECV, Parslow JP, Volkman JK, Blackburn SI and 22 others (2000) Huon Estuary study-environmental research for integrated catchment management and aquaculture. Final report to the Fisheries Research and Development Corporation project number 96/284. Report No. FRDC proj no 96/284, CSIRO Division of Marine Research. Marine Laboratories, Hobart, Tasmania. Also available at www. marine.csiro.au/research/sme/huonest/report/index.html

Cabrita MT, Brotas V (2000) Seasonal variation in denitrification and dissolved nitrogen fluxes in intertidal sediments of the Tagus estuary, Portugal. Mar Ecol Prog Ser 202:51-65

Cahoon LB (1999) The role of benthic microalgae in neritic ecosystems. Oceanogr Mar Biol 37:47-86

Cahoon LB, Safi KA (2002) Distribution and biomass of benthic microalgae in Manukau Harbour, New Zealand. NZ J Mar Freshw Res 36:257-266

Canuel EA, Martens CS (1993) Seasonal-variations in the sources and alteration of organic-matter associated with recently-deposited sediments. Org Geochem 20:563-577

Canuel EA, Freeman KH, Wakeham SG (1997) Isotopic compositions of lipid biomarker compounds in estuarine plants and surface sediments. Limnol Oceanogr 42:1570-1583 Cariou-Le Gall VCL, Blanchard GF (1995) Monthly HPLC measurements of pigment concentrations from an intertidal muddy sediment of Marennes-Oleron Bay, France. Mar Ecol Prog Ser 121:171-179

Cook PLM, Butler ECV, Eyre BD (2004a) Carbon and nitrogen cycling on intertidal mudflats of a temperate Australian estuary. I. Benthic metabolism. Mar Ecol Prog Ser 280:25-38

Cook PLM, Revill AT, Butler ECV, Eyre BD (2004b) Carbon and nitrogen cycling on intertidal mudflats of a temperate Australian estuary. II. Nitrogen cycling. Mar Ecol Prog Ser 280:39-54

Couch CA (1989) Carbon and nitrogen stable isotopes of meiobenthos and their food resources. Estuar Coast Shelf Sci 28:433-441

Currin CA, Newell SY, Paerl HW (1995) The role of standing dead Spartina alterniflora and benthic microalgae in salt marsh food webs: considerations based on multiple stable isotope analysis. Mar Ecol Prog Ser 121:99-116

Dalsgaard T, Nielsen LP, Brotas V, Viaroli P and 10 others (2000) Protocol handbook for NICE-nitrogen cycling in estuaries: a project under the EU research programme: Marine Science and Technology (MAST III). National Environmental Research Institute, Silkeborg

Davis MW, MacIntyre HL (1983) Effect of physical gradients on the production dynamics of sediment-associated algae. Mar Ecol Prog Ser 13:103-114

Degens ET, Behrendt M, Gotthardt B, Reppmann E (1968) Metabolic fractionation of carbon isotopes in marine plankton. II. Data on samples collected off the coasts of Peru and Ecuador. Deep-Sea Res 15:11-20

de Jonge VN (1980) Fluctuations in the organic carbon to chlorophyll a ratios for estuarine benthic diatom populations. Mar Ecol Prog Ser 2:345-353

Eaton JW, Moss B (1966) The estimation of numbers and pigment content in epipelic algal populations. Limnol Oceanogr 11:584-595

Findlay RH, Dobbs FC (1993) Quantitative description of microbial communities using lipid analysis. In: Kemp PF, Sherr BF, Sherr EB, Cole JJ (eds) Handbook of methods in aquatic microbial ecology. Lewis Publishers, Boca Raton, FL, p 271-284

Fry B, Sherr E (1984) $\delta^{13}$ C measurements as indicators of carbon flow in marine and freshwater ecosystems. Contrib Mar Sci 27:15-47

Grant J (1986) Sensitivity of benthic community respiration and primary production to changes in temperature and light. Mar Biol 90:299-306

Grossi V, Hirschler A, Raphel D, Rontani JF, de Leeuw JW, Bertrand JC (1998) Biotransformation pathways of phytol in recent anoxic sediments. Org Geochem 29:845-861

Heip CHR, Goosen NK, Herman PMJ, Kromkamp J, Middelburg JJ, Soetaert K (1995) Production and consumption of biological particles in temperate tidal estuaries. Oceanogr Mar Biol Annu Rev 33:1-149

Jeffrey SW, Vesk M (1997) Introduction to marine phytoplankton and their pigment signatures. In: Jeffrey SW, Mantoura RFC, Wright SW (eds) Phytoplankton pigments in oceanography: guidlines to modern methods. UNESCO, Paris, p 37-84

Kharlamenko VI, Kiyashko SI, Imbs AB, Vyshkvartzev DI (2001) Identification of food sources of invertebrates from the seagrass Zostera marina community using carbon and sulfur stable isotope ratio and fatty acid analyses. Mar Ecol Prog Ser 220:103-117

Kristensen E (1993) Seasonal variations in benthic community metabolism and nitrogen dynamics in a shallow, organic- 
poor Danish lagoon. Estuar Coast Shelf Sci 36:565-586 Lucas CH, Holligan PM (1999) Nature and ecological implications of algal pigment diversity on the Molenplaat tidal flat (Westerschelde Estuary, SW Netherlands). Mar Ecol Prog Ser 180:51-64

MacGregor BJ, Van Mooy B, Baker BJ and 5 others (2001) Microbiological, molecular biological and stable isotopic evidence for nitrogen fixation in the open waters of Lake Michigan. Environ Microbiol 3:205-219

Meziane T, Tsuchiya M (2000) Fatty acids as tracers of organic matter in the sediment and food web of a mangrove/intertidal flat ecosystem, Okinawa, Japan. Mar Ecol Prog Ser 200:49-57

Meziane T, Tsuchiya M (2002) Organic matter in a subtropical mangrove-estuary subjected to wastewater discharge: origin and utilisation by two macrozoobenthic species. J Sea Res 47:1-11

Meziane T, Bodineau L, Retiere C, Thoumelin G (1997) The use of lipid markers to define sources of organic matter in sediment and food web of the intertidal salt-marsh-flat ecosystem of Mont-Saint-Michel Bay, France. J Sea Res 38:47-58

Middelburg JJ, Barranguet C, Boschker HTS, Herman PMJ, Moens T, Heip CHR (2000) The fate of intertidal microphytobenthos carbon: an in situ ${ }^{13} \mathrm{C}$-labeling study. Limnol Oceanogr 45:1224-1234

Moers MEC, Jones DM, Eakin PA, Fallick AE, Griffiths H, Larter SR (1993) Carbohydrate diagenesis in hypersaline environments: application of GC-IRMS to the stableisotope analysis of derivatized saccharides from surficial and buried sediments. Org Geochem 20:927-933

Porra RJ, Pfündel EE, Engel N (1997) Metabolism and function of photosynthetic pigments. In: Jeffrey SW, Mantoura RFC, Wright SW (eds) Phytoplankton pigments in oceanography: guidelines to modern methods. UNESCO, Paris, p 85-178

Rau GH, Low C, Pennington JT, Buck KR, Chavez FP (1998) Suspended particulate nitrogen $\delta^{15} \mathrm{~N}$ versus nitrate utilization: observations in Monterey Bay, CA. Deep-Sea Res II 45:1603-1616

Riera P $(1998) \delta^{15} \mathrm{~N}$ of organic matter sources and benthic invertebrates along an estuarine gradient in MarennesOleron Bay (France): implications for the study of trophic structure. Mar Ecol Prog Ser 166:143-150

Rohjans D, Brocks P, Scholz-Böttcher BM, Rullkötter J (1998) Lipid biogeochemistry of surface sediments in the Lower Saxonian Wadden Sea, northwest Germany, and the effect of the strong winter 1995-1996. Org Geochem 29: 1507-1516

Schultz DJ, Calder JA (1976) Organic carbon ${ }^{13} \mathrm{C} /{ }^{12} \mathrm{C}$ variations in estuarine sediments. Geochim Cosmochim Acta 40:381-385

Shi W, Sun MY, Molina M, Hodson RE (2001) Variability in the distribution of lipid biomarkers and their molecular isotopic composition in Altamaha estuarine sediments: implications for the relative contribution of organic matter from various sources. Org Geochem 32:453-467

Editorial responsibility: Otto Kinne (Editor),

Oldendorf/Luhe, Germany
Stal LJ (1995) Physiological ecology of cyanobacteria in microbial mats and other communities. New Phytol 131:1-32

Stal LJ, Grossberger S, Krumbein WE (1984) Nitrogen fixation associated with the cyanobacterial mat of a marine laminated microbial ecosystem. Mar Biol 82:217-224

Summons RE, Jahnke LL, Hope JM, Logan GA (1999) 2-methylhopanoids as biomarkers for cyanobacterial oxygenic photosynthesis. Nature 400:554-557

Sun MY, Lee C, Aller RC (1993) Laboratory studies of oxic and anoxic degradation of chlorophyll-a in Long-Island Sound sediments. Geochim Cosmochim Acta 57:147-157

Thompson PA, Harrison PJ, Whyte JNC (1990) Influence of irradiance on the fatty acid composition of phytoplankton. J Phycol 26:278-288

Thornton SF, McManus J (1994) Application of organiccarbon and nitrogen stable-isotope and $\mathrm{C} / \mathrm{N}$ ratios as source indicators of organic-matter provenance in estuarine systems-evidence from the Tay Estuary, Scotland. Estuar Coast Shelf Sci 38:219-233

van Dongen BE, Schouten S, Sinninghe Damsté JS (2002) Carbon isotope variability in monosaccharides and lipids of aquatic algae and terrestrial plants. Mar Ecol Prog Ser 232:83-92

Vaskovsky VE, Khotimchenko SV, Xia BM, Li HF (1996) Polar lipids and fatty acids of some marine macrophytes from the Yellow Sea. Phytochemistry 42:1347-1356

Verardo DJ, Froelich PN, MacIntyre A (1990) Determination of organic carbon and nitrogen in marine sediments using the Carlo Erba NA-1500 Analyzer. Deep-Sea Res A 37: $157-165$

Volkman JK, Johns RB, Gillan FT, Perry GJ (1980) Microbial lipids of an intertidal sediment. I. Fatty acids and hydrocarbons. Geochim Cosmochim Acta 44:1133-1143

Volkman JK, Jeffrey SW, Nichols PD, Rogers GI, Garland CD (1989) Fatty-acid and lipid-composition of 10 species of microalgae used in mariculture. J Exp Mar Biol Ecol 128: 219-240

Volkman JK, Barrett SM, Blackburn SI, Mansour MP, Sikes EL, Gelin F (1998) Microalgal biomarkers: a review of recent research developments. Org Geochem 29: 1163-1179

Volkman JK, Rohjans D, Rullkötter J, Scholz-Böttcher BM, Liebezeit G (2000) Sources and diagenesis of organic matter in tidal flat sediments from the German Wadden Sea. Cont Shelf Res 20:1139-1158

Wannigama GP, Volkman JK, Gillan FT, Nichols PD, Johns RB (1981) A comparison of lipid components in fresh and dead leaves and pneumatophores of the mangrove Avicenna marina. Phytochemistry 20:659-666

Wilson S, Burns K, Codi S (2001) Identifying sources of organic matter in sediments from a detritivorous coral reef fish territory. Org Geochem 32:1257-1269

Wright SW, Jeffrey SW, Mantoura RFC, Llewellyn CA, Bjornland T, Repeta D, Welschmeyer N (1991) Improved HPLC method for the analysis of chlorophylls and carotenoids from marine phytoplankton. Mar Ecol Prog Ser 77: 183-196

Submitted: November 15, 2003; Accepted: May 27, 2004

Proofs received from author(s): September 22, 2004 